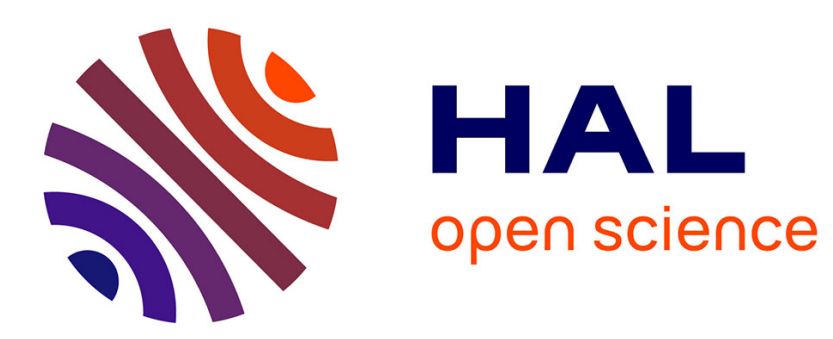

\title{
Local Versus International Crises, Foreign Subsidiaries and Bank Stability: Evidence from the MENA Region
}

Tammuz Alraheb, Amine Tarazi

\section{To cite this version:}

Tammuz Alraheb, Amine Tarazi. Local Versus International Crises, Foreign Subsidiaries and Bank Stability: Evidence from the MENA Region. 2016. hal-01270806

\section{HAL Id: hal-01270806 \\ https://hal-unilim.archives-ouvertes.fr/hal-01270806}

Preprint submitted on 24 Feb 2016

HAL is a multi-disciplinary open access archive for the deposit and dissemination of scientific research documents, whether they are published or not. The documents may come from teaching and research institutions in France or abroad, or from public or private research centers.
L'archive ouverte pluridisciplinaire HAL, est destinée au dépôt et à la diffusion de documents scientifiques de niveau recherche, publiés ou non, émanant des établissements d'enseignement et de recherche français ou étrangers, des laboratoires publics ou privés. 


\title{
Local Versus International Crises, Foreign Subsidiaries and Bank Stability: Evidence from the MENA Region.
}

\author{
Tammuz ALRAHEB ${ }^{\mathrm{ab}}$, Amine TARAZI $^{\mathrm{ac}}$ \\ ${ }^{a}$ Université de Limoges, LAPE, 5 rue Félix Eboué, 87031 Limoges Cedex, France.
}

Preliminary draft: January 28, 2015.

Please do not quote without the permission of the authors.

\begin{abstract}
We investigate the impact of global and local crises on bank stability and examine the effect of owning bank subsidiaries in other countries. We consider banks from MENA countries which experienced both types of crises during our sample period. Our findings highlight a negative impact of the global financial crisis of 2007-2008 on bank stability but, on the whole, no negative impact of the 'Arab Spring'. A deeper investigation shows that owning subsidiaries outside the home country is a source of increased fragility during normal times, yet a source of higher stability during the 'Arab Spring' but not during the global financial crisis. Moreover, owning foreign subsidiaries in one or two world regions is insufficient to neutralize the 'Arab Spring' crisis, while being present in three or more regions is more stabilizing during the 'Arab Spring' but also more destabilizing during the global financial crisis. Our findings contribute to the literature examining bank stability and have several policy implications.

JEL classification: G01, G21, G28

Keywords : Financial crises, Bank stability, Subsidiaries, MENA region.
\end{abstract}

\footnotetext{
${ }^{b}$ Corresponding author. Email: tammuz.al-raheb@etu.unilim.fr (T. Al Raheb).

${ }^{c}$ Email: amine.tarazi@unilim.fr (A. Tarazi)
} 


\title{
Local Versus International Crises, Foreign Subsidiaries and Bank Stability: Evidence from the MENA Region.
}

\begin{abstract}
We investigate the impact of global and local crises on bank stability and examine the effect of owning bank subsidiaries in other countries. We consider banks from MENA countries which experienced both types of crises during our sample period. Our findings highlight a negative impact of the global financial crisis of 2007-2008 on bank stability but, on the whole, no negative impact of the 'Arab Spring'. A deeper investigation shows that owning subsidiaries outside the home country is a source of increased fragility during normal times, yet a source of higher stability during the 'Arab Spring' but not during the global financial crisis. Moreover, owning foreign subsidiaries in one or two world regions is insufficient to neutralize the 'Arab Spring' crisis, while being present in three or more regions is more stabilizing during the 'Arab Spring' but also more destabilizing during the global financial crisis. Our findings contribute to the literature examining bank stability and have several policy implications.
\end{abstract}

JEL classification: G01, G21,G28.

Keywords : Financial crises, Bank stability, Subsidiaries, MENA region.

\section{Introduction}

The literature has documented numerous cases where political instability or crisis has significantly increased financial market volatility (Goodell \& Vähämaa, 2013). Moreover, such episodes are also known to severely affect the stability of the banking system leading to an increase in the probability of a banking crisis (Vaugirard, 2007) (Khandelwal \& Roitman, 2013). Several examples of contagion to other countries are also evident starting from 1994-1995 with the 'Tequila Crisis', the 'Asian Flu' of 19971998, the 'Russian Virus of 1998, the 1998-1999 'Brazilian Crisis', and ending with the 'Subprime Crisis' in 2007-2008. These prior incidents have shown that shocks from one country can overwhelm "within a matter of days countries having no apparent link with the crisis country" (Mati, 2008). 
In this paper, we take the MENA region as a laboratory to investigate possible differences between international and local shocks. Specifically, we examine the impact of the so-called 'Arab Spring' and the global financial crisis of 2007-2008 on the stability of banks in the MENA region and whether stability is differently affected by such crises. Moreover, we investigate how owning foreign subsidiaries makes banks more or less vulnerable in their home country during normal times and during such shocks, either regional or international.

MENA banks are, on average, better capitalized and more profitable than banks in the U.S. and the Eurozone ${ }^{1}$ but their recent expansion might also make them more exposed as they tend to play a more important role at the regional but also global level through the subsidiaries they own worldwide. MENA region ranks second after East Asia, in terms of bank assets to GDP ratio, and ahead of Eastern Europe, South Asia, and Latin America (Anzoategui, et al., 2010). Furthermore, Islamic banks in the region account for $72 \%$ of total Islamic banks assets in the world. Consequently, investigating the vulnerability of MENA banks to regional or global shocks is an important question.

The so-called 'Arab Spring' started in Tunisia in December 2010 and spread to other countries in the Middle East and North Africa region (MENA). The political crisis unfolded to Egypt in January 2011, finding its way to Yemen in the same month and to Libya and Bahrain in the following February, and finally reaching Syria in March. The 'Arab Spring' led to political reforms and new policies and regulations in other countries, to prevent the possibility of similar uprisings. As a consequence, financial markets negatively responded to the turbulences recording, for example, a 16\% drop in Egypt to the lowest level in 2 years while the Tunisian stock exchange also declined significantly (Chau, et al., 2014). The MENA region has had a long history of political instability, violence, and war. Such turbulences have had a negative, and sometimes devastating, effect on economic growth in the region (Tang \& Abosedra, 2014). The magnitude of the current political unrest, nonetheless, is unprecedented before.

\footnotetext{
${ }^{1}$ Equity to total assets is at an average of $11.4 \%$ in the MENA region compared to $11.2 \%$ and $6.9 \%$ in the U.S. and the Eurozone, respectively. On average the return on equity of MENA banks is also higher : $13.5 \%, 12.2 \%$ and $5.9 \%$ in MENA, The U.S., and the Eurozone, respectively (source: Bankscope).
} 
Few papers have examined the impact of the 'Arab Spring' on financial system stability. (Chau et al., 2014) examine the volatility of major stock markets in the MENA region and find that the 'Arab Spring' is associated with an increase in volatility of all MENA stock markets. Their results also highlight that the observed market volatility is mainly driven by Islamic indices rather than commercial ones. Using a sample of 41 banks, (Love \& Ariss, 2014) study the macro-economic shock transmission of the 'Arab Spring' to banks in Egypt. Their findings confirm that macroeconomic shocks are actually transmitted to the banking sector. Moreover, the drop in capital inflows following the 'Arab spring' events is found to be a key determinant of the loan portfolio quality in their sample. Ghosh (2015) investigates the effects of the 'Arab Spring' on the risk and returns of banks in 12 MENA countries encompassing three of the six countries directly affected by the political turmoil. His results show lower profitability and increased risk for banks in countries that were affected by the 'Arab Spring' compared to the remaining countries in the sample. Moreover, Islamic banks showed an increase in risk compared to their conventional (commercial) counterparts.

Political instability occurs when either planned or unplanned political events happen; elections are a good example of the first event, while uprisings are an example of the second. Other shocks that can have an effect on the financial sector are terrorist attacks (9/11 attacks) or wars (Gulf Wars). The main bulk of political instability literature has focused on the effects of elections on different aspects of financial markets and banks. Białkowski, Gottschalk, qnd Wisniewski (2008) find an increase in market return volatility linked to election periods due to "narrow margin of victory, lack of compulsory voting laws, change in the political orientation of the government, or the failure to form a government with parliamentary majority". Julio \& Yook (2012) document a decline in corporate investment expenditures during election years. (Pástor \& Veronesi, 2013) show that political uncertainty commands a risk premium in stock markets. (Önder \& Özyıldırım, 2013) find that, during election years, state owned banks have significantly higher shares in the credit market, while the results obtained by Chen and Liu (2013) tell a different story, private banks showing higher loan growth and ROA. Francis, Hasan, and Zhu (2014) show that both political uncertainty and the exposure to it increase the cost of debt and tighten bank loan contracting. Charles and Olivier (2014) link large stock 
market volatility shocks, over a period ranging between 1928 to 2013, to several events including elections, wars, and terrorist attacks, among others. Liu and Ngo (2014) show that bank failure is around $45 \%$ less likely to happen during the election year.

Other risk and stability studies of the MENA region find a negative relationship between financial openness and bank risk taking and a positive relationship between disclosure and stability (Bourgain, et al., 2012). (Srairi, 2013) finds a negative relationship between ownership concentration and risk taking. He also finds state-owned banks to be riskier than privately owned ones, Islamic banks being as stable as their conventional counterparts. Larger banks that are less diversified and which operate in concentrated markets are also found to be more stable (Maghyereh \& Awartani, 2014).

(Saeed \& Izzeldin, 2014) examine 106 Islamic and conventional banks in GCC ${ }^{2}$ countries and 3 non GCC countries in the MENA region. On the one hand, they find that a decrease in default risk for conventional banks is associated with a decrease in efficiency. Islamic banks, on the other hand, show no tradeoff between default risk and efficiency.

This paper extends the existing literature in several directions. First, we examine the influence of banks' foreign subsidiaries ${ }^{3}$ on the stability of 'home' rather than 'host' banking sector during both regional and global shocks (political and financial). Second, to our best knowledge, while earlier studies have mainly focused on the effect of the 'Arab Spring' on stock market volatility in MENA countries (Chau et al., 2014), we examine its implications on the safety and soundness of banks in all MENA region countries. Third, in the process, we also investigate the determinants of bank stability in the MENA region as a whole and provide insights for better risk monitoring and supervision by regulators. Third, we compare the impact of the global financial crisis of 2007-2008 and that of the regional political instability of 2011-2012 on the stability of the banking sector.

We consider a sample of 336 banks from 21 MENA countries covering the 20042012 period, and find that banks did not suffer from lower stability during the 'Arab Spring'. Conversely, the global financial crisis had a greater effect on the region as a

\footnotetext{
${ }^{2}$ The Gulf Cooperation Council (GCC) includes Bahrain, Kuwait, Oman, Qatar, Saudi Arabia, and the United Arab Emirates.

${ }^{3}$ The term 'foreign subsidiaries' will be used throughout this paper to refer to subsidiaries owned by banks in the sample, and are operating in countries other than the country of main operations.
} 
whole by significantly decreasing bank stability. We find that financial openness measured by the banks' ability to own subsidiaries outside their home country was a source of increased fragility throughout the sample years, yet a source of higher stability during the 'Arab Spring' but not during the global financial crisis. This positive effect of owning foreign subsidiaries on stability during the 'Arab Spring' is mainly associated with a decrease in leverage risk, suggesting a possible transfer of funds during the regional crisis. Additionally, banks with subsidiaries in South America show lower stability throughout the sample period, while owning subsidiaries in South America, Europe, and the MENA region contributes to higher stability during the Arab Spring. Subsidiaries located in Europe are found to negatively affect MENA region banks during the global financial crisis. Lastly, owning foreign subsidiaries in one or two world regions does not hedge from the effects of the 'Arab Spring', while being present in three or more regions is more stabilizing during the Arab Spring and more destabilizing during the global financial crisis. Being either a conventional bank or an Islamic bank (including a conventional bank with an Islamic window) does not significantly impact stability. A negative relationship is found between bank stability and ownership concentration and loan growth.

The paper unfolds as follows. Section 2 provides insight on the banking sector in the MENA region. Definitions of dependent and independent variables, in addition to the empirical model are presented in section 3. Section 4 documents the regression results, and additional robustness checks can be found in section 5. Finally section 6 concludes.

\section{MENA banking sector background}

The banking sector in the MENA region, and the entire financial environment, have undergone profound transformation and deregulation throughout the past two decades. Despite being relatively young (most banks established in the 1970s or later), banking sectors across the MENA region are considered among the "biggest and deepest" in the emerging and developing world (Anzoategui, et al., 2010). However, it should be noted that some of the region countries are still in "early stages of financial development and have a weak legal and supervisory environment" (Bourgain, et al., 2012). The importance of the MENA region stems from lying at the "cross-roads of major sea and 
trading routes with easy access to Europe, Africa, and the near East" (Malik \& Awadallah, 2013), in addition to its fast growing economies and financial sectors. It includes the rapidly expanding, oil rich countries as well as a mixed banking sector of Islamic and conventional banks that contains the largest Islamic banks (Olson \& Zoubi, 2011). Countries in the MENA region are considered homogeneous to some extent, "with a population of 350 Million people sharing a common language, culture, and rich trading civilization" (Malik \& Awadallah, 2013). Nevertheless, differences such as in the size of the economy, financial development and per capita GDP are evident. As such, the World Bank classification distributed MENA countries into three income levels being: Highincome, Upper-middle-income, and Lower-middle-income (8, 6, and 7 countries, respectively). To shed light on the characteristics of the banking sector in the region, selected indicators are listed in table (1). Loans to deposits measure the ability of banks to transfer costly deposits into profiting loans with a higher ratio indicating higher intermediation efficiency. However, a ratio exceeding one suggests that part of the lending is funded by sources other than deposits, which could lead to instability (Beck, et al., 2009). Overheads to total assets and net interest margin reflect the intermediation cost of banks, higher values signal an elevated level of cost inefficiency and intermediation cost (Soedarmono \& Tarazi, 2013). Concentration is the ratio of the three largest bank's assets to total banking sector assets, while ROA is return on assets (profitability) and Zscore is an indicator of bank stability. A higher ratio of Z-score indicates a more stable banking sector ${ }^{4}$. As shown in table (1), banking sectors in the MENA region are more stable and more profitable than their counterparts in OECD countries. They are also less efficient and slightly more concentrated.

The majority of the Gulf Cooperation Council (GCC) countries are above the region average with regards to loans to deposits, net interest margin, and ROA. On the contrary, these countries are below average when it comes to overheads to total assets and Z-score. In other words, banks in GCC countries are more profitable, more costefficient, and riskier than other banks in the region.

Banks in the MENA region started as either state or family owned and are still the dominant financial institutions in essentially bank based economies even though some

\footnotetext{
${ }^{4}$ All these figures are taken from the World Bank Financial Development and Structure Dataset
} 
countries have active financial markets. During the past couple of decades, many stateowned banks were privatized, family banks were listed, Islamic banks gained higher market shares, and foreign banks entered the market due to reduced barriers of entry. The presence of international financial intermediaries led to domestic banks enhancing their organizational and capital structure to remain competitive (Turk-Ariss, 2009). Moreover, some of the region's banks have implemented pillars 1, 2, and 3 of the Basel II accord since 2005 and will be gradually implementing Basel III recommendations starting late $2014^{5}$.

\section{[[ insert table 1 here ]]}

\section{Data, variables, and Empirical Models}

In this section, before presenting our empirical model and our variables, we describe our sample.

\subsection{Sample}

The sample considered in this study is an unbalanced panel of annual bank-level data ranging from 2004 to 2012 . We eliminate extreme values at $1 \%$ and $99 \%$ of all variables to mitigate the impact of outliers. After filtering, the sample includes 3024 bank-year observations, representing 336 banks (246 conventional and 90 Islamic banks) from the 21 countries that constitute the MENA region. The number of banks in each country is listed between brackets as follows: Algeria (16), Bahrain (32), Djibouti (2), Egypt (26), Iran (16), Iraq (16), Israel (11), Jordan (15), Kuwait (17), Lebanon (46), Libya (9), Malta (11), Morocco (14), Oman (8), Palestine (5), Qatar (10), Saudi Arabia (13), Syria (15), Tunisia (18), UAE (26), Yemen (10). The sample includes state-owned and privately-owned banks and both listed and non-listed banks. Bank level data are extracted from Bankscope - Bureau van Dijk Database. Data for ownership are doublechecked against banks' annual reports. Classification of bank type (Islamic, conventional with Islamic window, and conventional) is crossed-checked with their respective

\footnotetext{
${ }^{5}$ In the (FSI-BIS, 2012) (FSI-BIS, 2014) surveys, Kuwait was the first country (2005) of their survey sample to start implementing the Basel II pillars, while Egypt was the last one (2011).
} 
websites for accuracy. Country-level variables are collected from the world bank database.

\subsection{Definition of variables}

\subsubsection{Dependent variables}

The main dependent variable is the Z-score, a widely used proxy of bank risk and stability in the literature (Beck \& Laeven, 2006) (Boyd, et al., 2007) ( Laeven \& Ross , 2007) (Laeven \& Levine, 2009) (Demirguc-Kunt \& Huizinga, 2010) (Fu, et al., 2014). This index is defined as:

$$
\mathrm{Z} \text {-score }=\frac{\mathrm{ROA}+\mathrm{CAR}}{\sigma \mathrm{ROA}}
$$

Where ROA is the return on assets, CAR is the ratio of total equity to total assets, and $\sigma \mathrm{ROA}$ is the standard deviation of ROA. We apply moving mean and standard deviation estimates with a three-year window. This risk measure is associated with the probability of bank failure; it represents the number of standard deviations below the expected value of bank's return on assets before equity is depleted and the bank is insolvent. Higher levels of Z-score are linked to higher levels of stability, as Z-score is the inverse of the probability of insolvency (Boyd \& Runkle, 1993) (Boyd, et al., 2006).

To identify the driving component of the Z-score, we follow (Goyeau \& Tarazi, 1992) (Lepetit, et al., 2008), (Barry, et al., 2011), and (Köhler, 2014) in breaking the Z-score into its two main components $\mathrm{Z} 1$ and $\mathrm{Z} 2$ and using them as dependent variables:

$$
\mathrm{Z1}=\frac{\frac{\text { average ROA }}{\sigma \mathrm{ROA}}}{\mathrm{Z} 2=\frac{\text { average CAR }}{\sigma \mathrm{ROA}}}
$$

$\mathrm{Z} 1$ is a proxy for asset risk, while Z2 denotes leverage risk. An increase in Z1 (Z2) is associated with a decrease in asset (leverage) risk.

Z-score, Z1, and Z2 are highly skewed, however the natural logarithm of these variables is normally distributed and commonly used in the banking literature (i.e. Laeven and Levine, 2009). 


\subsubsection{Independent variables}

\subsubsection{Main variables}

To capture the effect of the 'Arab Spring' on the stability of the banking sector in the MENA region, a dummy variable ASdate is introduced. ASdate takes the value of one if the year is 2011 or 2012, or zero otherwise. To account for the global financial crisis of 2007-2008, we include a dummy variable, GFC, which holds the value of one if the year is 2008 or 2009 , or zero for remaining years ${ }^{6}$.

We also introduce a variable, FS, to control for the effects of owning foreign subsidiaries. The term foreign subsidiaries is used here to express subsidiaries operating in a country other than the home country of the mother bank. The variable included in the main regression is a dummy variable that takes the value of one if the bank holds one or more subsidiaries and zero otherwise, while a continuous variable reflecting the actual number of owned subsidiaries, FS_C, is used as a robustness check. We also include interaction terms FS_AS and FS_GFC to account for the effects of owning foreign subsidiaries during the Arab Spring and during the global financial crisis of 2007-2008, respectively. Most of the research dedicated to subsidiaries has focused on their effect on the host country banking industry and found on the one hand that they provide increased stability during host country crisis, higher access to finance, increased efficiency and competitiveness, and lower lending costs (Claessens, 2006), (Wu, et al., 2011), (Jeon, et al., 2011), and (Bremus \& , 2015). On the other hand, they could transmit shocks from home country and destabilize host countries, (Popov \& Udell, 2012) (Jeon, et al., 2013). In general, owning subsidiaries could be beneficial to the mother bank in terms of stability if they perform well; through channeling funds and profits that could compensate for any volatility in funding and earnings of the mother bank. They could also be a source of increased instability if they were in need of constant liquidity injection. Building on the existing literature, we expect these subsidiaries to be a source of stability during a domestic crisis, and a source of instability during a global crisis. To further examine the effects of owning foreign subsidiaries we group them into separate world regions and define six variables that indicate their location : Africa (FS_Africa), (South America

\footnotetext{
${ }^{6}$ (Neaime, 2012) shows that the crisis reached the MENA region stock markets in 2008, decreasing stock market capitalization from 1,189,187 (Mil USD) in 2007 to 645,211 (Mil USD) in 2008. (Guyot, et al., 2014) also document a sharp decrease in Egypt market capitalization in 2008, compared to 2007.
} 
(FS_S_America), Asia (FS_Asia), Australia (FS_Australia), Europe (FS_Europe), MENA (FS_MENA), and the U.S. (FS_USA). We also investigate the possible effects of owning subsidiaries in only one region, two regions, and three or more regions.

\subsubsection{Control variables}

Throughout the years, governmentally owned and privately owned banks have become somewhat identical in their service and product range, despite having different objectives. They also compete in the same markets and under the same regulations. Public and private banks became "virtually indistinguishable in terms of their range of activities" (Iannotta, et al., 2007). To account for ownership type, state-owned or privateowned, we follow (Barry, et al., 2011) and (Iannotta, et al., 2013) by introducing a continuous variable, GOBs, defined as the actual percentage of the bank's equity held by the local government.

We also identify three types of banks which are in theory of different nature: Islamic banks, conventional banks with Islamic window, and purely conventional (commercial) banks. Dummy variables Conventional, Islamic, and Window take the value of one if the bank is conventional, Islamic, or conventional with Islamic window, respectively, and zero otherwise. Islamic banks could be found to be less stable than conventional ones (Čihák \& Hesse, 2010), more stable (Bourkhis \& Nabi, 2013), or even equally stable/unstable (Abedifar, et al., 2013).

The variable ' $\mathrm{OC}$ ' refers to the shareholder ownership concentration, i.e. the highest share of equity held by a single shareholder. Although a noteworthy number of studies have evaluated the relationship between ownership concentration and risk taking, the sign and nature of the relationship, however, is ambiguous. On the one hand, banks with higher ownership concentration could exhibit higher risk taking and insolvency risk (Haw, et al., 2010) (Laeven \& Levine, 2009) as the increase in ownership concentration could result in an increase in the shareholders' power to engage in riskier activities based on their interests. On the other hand, an increase in ownership concentration is found to be related to lower risk (Shehzad, et al., 2010) (García-Marco \& Robles-Fernández, 2008) due to increased corporate control and monitoring of management decisions and actions. 
We also control for leverage by including the capital asset ratio, CAR, defined as the ratio of equity to total assets. Higher equity provides greater cushion against losses and financial distress. It also indicates higher risk aversion and is expected to decrease moral hazard incentives and improve monitoring (Diamond, 1984). But higher capital could also increase banks' risk-taking capacity and therefore the impact on bank stability as a whole is unclear (Abedifar, et al., 2013).

We also include the ratio of non-performing loans to total loans, NPL, to reflect the quality of assets (Uhde \& Heimeshoff, 2009). This variable is expected to negatively affect bank stability. To capture the effect of bank size on stability, we introduce the logarithm of bank total assets: Size. Larger banks have better ability to diversify their risk and therefore are expected to be more stable. However, large banks might also have incentives to take on higher risk because of Too-Big-To-Fail policies and the presence of governmental bailouts (Demirgüç-Kunt \& Huizinga, 2013). Bhagat et al., 2015, find a negative relationship between bank size and stability, i.e. smaller banks being more stable than large banks. Their finding supports the moral hazard approach of Too-Big-To-Fail banks as these banks might be taking excessive risk knowing that their losses will be partially covered by regulators and hence taxpayers (Tabak, et al., 2013). Beck et al., 2013, results, however, show that banks with larger size are more stable.

Risk is also affected by bank diversification. Specifically, engaging in noninterest activities diversification is found to generate higher higher earnings volatility and lower stability (Stiroh \& Rumble, 2006) (Stiroh, 2006) (Lepetit, et al., 2008) (De Jonghe, 2010). However, some studies provide evidence of higher risk adjusted returns, lower cost of debt and increased stability (Gallo, et al., 1996) (Deng, et al., 2007) (Chiorazzo, et al., 2008) (Sanya \& Wolfe, 2011). This diversification benefit, however, depends on the type of the activities undertaken by banks. For instance insurance activities are found to reduce the probability of bank failure whereas market activities have the opposite effect (Kwan \& Laderman, 1999) (DeYoung \& Torna, 2013).

In our study, reliance on nontraditional banking activities is captured by a variable named Divers defined as :

$$
\text { Divers }=1-\mid \quad \text { NIR }- \text { OOI } \mid
$$

NIR: net interest revenue, OOI: other operating income, OI: operating income. 
We also control for concentration by considering the sum of the squared weights of banks assets for every country and in each year, HHI. A higher value indicating higher concentration in the banking industry. Higher concentration is expected to either increase or lower bank stability. Higher market share and franchise value positively affect profitability and provide incentives to take lower risk because of higher bankruptcy costs. This, in turn, is expected to enhance bank stability (Keeley, 1990) (Matutes \& Vives, 2000) (Hellman, et al., 2000) (Allen \& Gale, 2004). Other studies, nonetheless, find the opposite impact because higher market power enables banks to charge higher rates possibly increasing borrowers' default risk which could in turn negatively affect bank stability. Higher market concentration levels could also induce moral hazard, especially in the presence of governmental support (Boyd, et al., 2006) (Fu, et al., 2014) (De Nicoló \& Loukoianova, 2007).

We also account for loan growth, which is also expected to affect bank stability, by introducing the yearly growth rate of gross loans, GGL. (Foos, et al., 2010) find evidence that loan growth is associated with higher risk taking and lower bank stability, as higher loan growth could be attributed to poorer screening process or more aggressive expansion strategies. Finally, several variables are included to control for the level and growth of a given country's income, and the impact of foreign direct investment. Specifically, we introduce the natural logarithm of GDP per capita, GDP, its growth rate, GDP_Growth, and the percentage of change in direct foreign investment (FI_Growth).

\subsection{Empirical model}

To test the impact of the 'Arab Spring' on bank stability in the region as a whole, and to compare it to the impact of the global financial crisis, we consider the following models:

Z-Score $_{\mathrm{ij}, \mathrm{t}}=\alpha_{\mathrm{i}}+\beta_{1}$ Arab Spring $\mathrm{t}+\beta_{2}$ FS $_{\mathrm{ij}, \mathrm{t}}+\beta_{3}$ GOBs $_{\mathrm{ij}, \mathrm{t}}+\beta_{4}$ Type $\mathrm{ij, \textrm {t }}+$ $\sum_{k=1}^{7} \beta 5$ Controls ij, $\mathrm{t}+\sum_{k=1}^{3}$ Country - Level $\mathrm{j}, \mathrm{t}+\boldsymbol{\lambda}_{\mathrm{j}}+\varepsilon_{\mathrm{ij}, \mathrm{t}}$

Z-Score $_{\mathrm{ij}, \mathrm{t}}=\alpha_{\mathrm{i}}+\beta_{1}$ Global Financial Crisis $_{\mathrm{t}}+\beta_{2}$ FS $_{\mathrm{ij}, \mathrm{t}}+\beta_{3}$ GOBs $_{\mathrm{ij}, \mathrm{t}}+\beta_{4}$ Type $_{\mathrm{ij}, \mathrm{t}}+$ $\sum_{k=1}^{7} \beta 5$ Controls $\mathrm{ij}, \mathrm{t}+\sum_{k=1}^{3}$ Country - Level $\mathrm{j}, \mathrm{t}+\boldsymbol{\lambda}_{\mathrm{j}}+\varepsilon_{\mathrm{ij}, \mathrm{t}}$ 
Where Z-Score is a proxy for bank stability. Dummies for the 'Arab Spring' and the global financial crisis are presented in equations (2) and (3). FS is a dummy variable that takes the value of one if the bank owns one or more foreign subsidiaries, zero otherwise. GOBs is the share of governmental ownership of the bank. Type represents a measure of three categories of bank type: Islamic banks, conventional banks with Islamic window, and pure conventional banks. Controls represent a vector of variables that are commonly used to control for bank characteristics. Country-Level is a vector of variables representing country control variables. $\boldsymbol{\lambda}$ is the country fixed effects.

Z-Score is also replaced by its two components, Z1 (asset risk) and Z2 (leverage risk) in equations (2) and (3) to further investigate the sources of stability:

$\mathrm{Z}_{\mathrm{ij}, \mathrm{t}}=\alpha_{\mathrm{i}}+\beta_{1}$ Arab Spring $_{\mathrm{t}}+\beta_{2}$ FS $_{\mathrm{ij}, \mathrm{t}}+\beta_{3}$ GOBs $_{\mathrm{ij}, \mathrm{t}}+\beta_{4}$ Type $_{\mathrm{ij}, \mathrm{t}}+\sum_{k=1}^{7} \beta 5$ Controls $\mathrm{ij}, \mathrm{t}$ $+\sum_{k=1}^{3}$ Country - Level $\mathrm{j}, \mathrm{t}+\boldsymbol{\lambda}_{\mathrm{j}}+\varepsilon_{\mathrm{ij}, \mathrm{t}}$

$\mathrm{Z1}_{\mathrm{ij}, \mathrm{t}}=\alpha_{\mathrm{i}}+\beta_{1}$ Global Financial Crisis $\mathrm{t}+\beta_{2} \mathrm{FS}_{\mathrm{ij}, \mathrm{t}}+\beta_{3}$ GOBs $_{\mathrm{ij}, \mathrm{t}}+\beta_{4}$ Type $_{\mathrm{ij}, \mathrm{t}}+$

$\sum_{k=1}^{7} \beta$ Controls ij, $\mathrm{t}+\sum_{k=1}^{3}$ Country - Level $\mathrm{j}, \mathrm{t}+\boldsymbol{\lambda}_{\mathrm{j}}+\varepsilon_{\mathrm{ij}, \mathrm{t}}$

$\mathrm{Z}_{\mathrm{ij}, \mathrm{t}}=\alpha_{\mathrm{i}}+\beta_{1}$ Arab Spring $_{\mathrm{t}}+\beta_{2} \mathrm{FS}_{\mathrm{ij}, \mathrm{t}}+\beta_{3}$ GOBs $_{\mathrm{ij}, \mathrm{t}}+\beta_{4}$ Type $_{\mathrm{ij}, \mathrm{t}}+\sum_{k=1}^{7} \beta 5$ Controls $\mathrm{ij}, \mathrm{t}$ $+\sum_{k=1}^{3}$ Country - Level $\mathrm{j}, \mathrm{t}+\boldsymbol{\lambda}_{\mathrm{j}}+\varepsilon_{\mathrm{ij}, \mathrm{t}}$

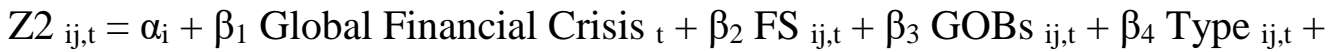

$\sum_{k=1}^{7} \beta 5$ Controls ij, $\mathrm{t}+\sum_{k=1}^{3}$ Country - Level $\mathrm{j}, \mathrm{t}+\boldsymbol{\lambda}_{\mathrm{j}}+\varepsilon_{\mathrm{ij}, \mathrm{t}}$

\section{Results}

\subsection{Descriptive statistics}

Table (2) presents descriptive statistics of the variables used in this study. The maximum Z-score value (7.74) is recorded in Malta in 2010. The average Z-Score for the whole region is 3.59 with Djibouti exhibiting the lowest Z-Score average of 2.89 while Morocco and Lebanon show the highest average of 4.14. Year 2009 recorded the lowest average Z-Score (3.28) while 2012 recorded the highest (3.93).

The highest number of foreign subsidiaries owned by a regional bank is witnessed in Bahrain (74). The latter also records the highest number of banks that own one or more subsidiaries (20). 
$27 \%$ of the sample banks are Islamic, $11 \%$ are conventional banks with Islamic window, and the remaining $62 \%$ are purely conventional (commercial) banks. While 6 countries $^{7}$ out of the 21 in our sample do not have any Islamic banks or windows, Iran's banking system is $100 \%$ Islamic. Lebanon has the highest number of banks (46), whereas Bahrain leads the number of Islamic banks with 19 Islamic and 7 Islamic window banks.

Banks in Algeria record the highest average ownership concentration with 76.5\% of shares owned by one shareholder. Iraqi banks exhibit, on average, the highest ratio of equity to total assets (35\%) while Israel's average is the lowest at $6 \%$.

The highest non-performing loans to total loans ratio, NPL, of $83.2 \%$ is witnessed in Tunisia in 2011. Yemen has the highest average NPL (29\%) compared to Qatar (1.79\%). In terms of size (natural logarithm of total assets), The largest bank (18.05) is in UAE while the smallest bank is in Yemen (10.69). Overall, Saudi Arabia has the largest banks (average natural logarithm of total assets) whereas Iraq has the smallest ones. In terms of competition, Palestine has, on average, the most concentrated banking sector (HHI 0.53), while the banking sector in Lebanon is the least concentrated (HHI 0.09). However, in absolute values, the highest concentration can be found in Syria (0.67) in 2006. Iraq recorded the uppermost average loan growth in the region with 53\% compared to Israel at 5\% being the lowest, while the maximum value of loan growth is in Qatar (327\%) in 2010. The highest GDP per capita is in Qatar while the lowest is in Djibouti.

\section{[[ insert table 2 here ]]}

Table (3) shows the distribution of foreign bank subsidiaries owned by MENA banks in different world regions. Bahraini banks have the highest number of foreign subsidiaries with 167 subsidiaries covering all seven regions defined in our study, while Palestinian banks have the lowest number of foreign subsidiaries (only one) and Djibouti has none. MENA region ${ }^{8}$ is the home of the highest number of foreign subsidiaries (312) and Europe is the second highest (205). 90 Subsidiaries in total are in South America. A

\footnotetext{
7 These countries are Djibouti, Israel, Libya, Malta, Morocco, and Oman.

${ }^{8}$ This includes all subsidiaries outside the main country of operations, yet still within the MENA region.
} 
closer look shows that subsidiaries in the Cayman Islands (67) and The British Virgin Islands (12) constitute the highest numbers of subsidiaries operating in South America.

\section{[[ insert table 3 here ]]}

125 banks from the MENA region have foreign subsidiaries. Some of these banks choose to only expand in one geographical region, while others diversify their subsidiaries network by having a presence in several world regions. Table (4) shows the number of banks owning subsidiaries in one region, two regions, or three or more regions. Almost half (56) of the subsidiary-owning banks have chosen to operate outside their country in one region only, 33 of these banks operate in the MENA region.

\section{[[ insert table 4 here ]]}

Table (5) shows the correlation among all our variables and reveals no major collinearity issues.

\section{[[ insert table 5 here ]]}

\subsection{Regressions results}

The Hausman test favors the Fixed Effects (FE) model over the Random Effects (RE) model. However, when using FE, several variables that show little change over time in addition to time invariant dummies (such as public, Islamic, window ...) are omitted from the regression. To combine the benefits of $\mathrm{FE}$ and RE, i.e. include all relevant time invariant dummies, two alternatives are suggested in the literature; the (Plümper \& Troeger, 2007) fixed-effects vector decomposition model (FEVD) and the (Hausman \& Taylor, 1981) model. Our estimations are carried out using the Hausman-Taylor (HT) model $^{9}$.

Table (6) reports the results for stability (columns $1 \& 4$ ), asset risk (columns $2 \&$ 5) and leverage risk (columns $3 \& 6$ ). The ASdate dummy variable shows a positive and

\footnotetext{
${ }^{9}$ Some studies favor the HT model over the FEVD estimator. See for example, (Breusch, et al., 2011), (Breusch, et al., 2011) and (Greene, 2011). The HT model uses an instrumental variable approach to deal with the possible correlation between the explanatory variables and the unobserved individual effects. We follow (Baltagi, et al., 2003) in testing the validity of our choice of endogenous variables by running a Hausman test between the FE and HT estimators.
} 
significant relationship with individual bank stability This increase in stability during the 'Arab Spring' is mainly driven by lower leverage risk (column 3). However, when testing for the impact of the global financial crisis of 2007-2008, column 4 shows the opposite result indicating that banks in the MENA region are more vulnerable to international than regional shocks.

The results also show that owning subsidiaries in a foreign country, FS, is associated with lower levels of stability for the mother-bank throughout the sample period. Regarding the control variables, banks with partial or full governmental ownership show no difference in stability compared to private ones. Islamic banks and conventional banks with Islamic window also show no difference in stability compared to their conventional counterparts. This result is in line with (Abedifar, et al., 2013), who find no statistically significant difference in stability between Islamic and non-Islamic banking models. Nonetheless, column (2) shows that Islamic banks have higher asset risk than the conventional ones. Other results also reveal that higher ownership by the major shareholder, OC, and higher loan growth, GGL, are associated with lower stability. Finally, higher levels of GDP per capita growth are positively linked with bank stability.

To further investigate the effects of owning subsidiaries outside the main country of operations during a crisis period, we introduce two interaction terms; FS_AS and FS_GFC to capture the effect of owning subsidiaries in other countries during the 'Arab Spring' and during the Global Financial Crisis, respectively. Results in table (7) show that, during the 'Arab Spring', owning such subsidiaries is beneficial in terms of bank stability. Hence, although owning subsidiaries in foreign countries is detrimental for stability during normal times, it has the opposite effect during local political shocks. Furthermore, the results also reveal lower leverage risk for such banks during the 'Arab Spring' suggesting possible capital transfers to the country of origin during regional crises. Such a result is in line with those of (Cetorellia \& Goldberg, 2012) who show that in a response to a funding shock, parent banks reallocate funds back from the subsidiaries when they face a liquidity shortage. However, the coefficient associated to the other interaction term FS_GFC is not significant. Hence, owning subsidiaries in other countries does not alter the negative impact on bank stability of the global financial crisis of 2007- 
2008, possibly because the subsidiaries might be suffering from the crisis themselves (column 4).

\section{[[ insert table 7 here ]]}

For deeper insights, we group foreign subsidiaries based on their geographical location. These world regions are Africa, South America, Asia, Australia, Europe, MENA, and the U.S. ${ }^{10}$. Table (8) shows the results when adding these regions, as well as interaction terms between each of the regions and the Arab spring variable in the regressions. Subsidiaries in South America are shown to be a source of instability for their owning banks in normal times but to a lesser extent during the 'Arab Spring'. In our sample, such subsidiaries are mostly located in the tax haven countries: the Cayman Islands and the British Virgin Islands. Nonetheless, banks that own subsidiaries located in South America, Europe, and the MENA region enjoy better stability during the Arab Spring than during normal times, as can be seen in equations 2, 4, and 5 in table (8).

\section{[[ insert table 8 here ]]}

In table (9) we look more deeply into the impact of the global financial crisis of 20072008. The results show that on the whole owning subsidiaries in most part of the world does not alter the impact of the crisis on bank stability. However, owning subsidiaries in Europe during the global financial crisis negatively impacts the stability of the mother bank.

\section{[[ insert table 9 here ]]}

In table (9) we look more closely into the influence played by the number of world regions where banks are present. Owning foreign subsidiaries in three or more regions is a source of better stability during the Arab Spring [table (10) column 3], while it is a source of instability during the global financial crisis (column 6). Hence, being present in one or two regions might not be enough to offset the impact of the Arab Spring, but being present in three or more regions is effective. However, such a broad geographical presence makes banks more vulnerable to the global financial crisis.

\section{[[ insert table 10 here ]]}

\footnotetext{
${ }^{10}$ Australia is omitted from the regression due to low observations number.
} 


\section{Robustness checks}

In this section, we run various regressions to check the validity of the results shown in section 4.3. For brevity, we only comment on the robustness of the main variables of interest.

First, we substitute the HT model with the random effects model. The results from the RE estimator remain significant and support the findings of section 4.3 (table 11).

Second, instead of a binary variable, we use a continuous variable for foreign subsidiaries defined as the actual number of subsidiaries owned by each bank,. The results (see table 12) confirm that banks that own subsidiaries in foreign countries are less stable throughout the sample period, but more stable during the 'Arab Spring' period.

Finally, because only Arab speaking countries were directly affected by the 'Arab Spring' we restrict our sample to Arab speaking countries of the MENA region.. Specifically, we exclude Iran, Israel and Malta. Overall, our main findings remain unchanged (table (13)).

\section{Summary and concluding remarks}

Using a sample of 336 banks over the period from 2004 to 2012 in the 21 countries that comprise the MENA region, this study identifies the determinants of bank stability and examines the effects of both local crises, namely the 'Arab Spring', and international crises such as the global financial crisis of 2007-2008. Specifically, we investigate the possible effects on stability of owning subsidiaries outside the home-land of the mother bank during normal times and during the before mentioned crises.

On the whole, our results show that while the global financial crisis of 2007-2008 negatively impacted bank stability in the MENA region, however the 'Arab Spring' didn't have a negative impact. A deeper look shows that although owning subsidiaries outside the main country of operations proved to be a source of instability throughout the sample and during the global financial crisis of 2007-2008, yet these subsidiaries were a source of increased stability during the 'Arab Spring' by decreasing leverage risk. Such findings suggests a possible transfer of capital between the subsidiaries and the main bank. Furthermore, we find that banks that own subsidiaries in South America are less stable 
than other banks and that owning subsidiaries in South America, Europe, and the MENA region is better for stability during the 'Arab Spring' than during normal times. Finally, owning foreign subsidiaries in one or two world regions does not mitigate the effect of the 'Arab Spring'. Owning subsidiaries in three or more regions, however, is a source of higher stability during the 'Arab Spring', but at the expense of negatively affecting the stability of the mother banks during the global financial crisis.

Our findings have important policy implications. Although banks that expand their operations internationally by opening subsidiaries in different world regions appear to be more vulnerable in both normal times and during international shocks they are also found to be more resilient to local shocks possibly because of their ability to channel capital. Hence, such bank geographical diversification is only effective in improving stability during specific local shocks and has the opposite effect otherwise. To monitor and manage bank stability prudential regulation and bank supervision should closely account for the structure of banking groups and their international diversification the benefits of which could be counterintuitive. 


\section{Bibliography}

Laeven, L. \& Ross , L., 2007. Is there a diversification discount in financial conglomerates?. Journal of Financial Economics, 85(2), p. 331-367.

Abedifar, P., Molyneux, P. \& Tarazi, . A., 2013. Risk in Islamic Banking. Review of Finance, 17(6), pp. 2035-2096.

Abou El Sood, H., 2012. Loan loss provisioning and income smoothing in US banks pre and post the financial crisis. International Review of Financial Analysis, Volume 25, p. 64-72.

Allen, F. \& Gale, D., 2004. Competition and Financial Stability. Journal of Money, Credit and Banking, 36(3), pp. 453-480.

Amador, J. S., Gómez-González, J. E. \& Pabón, A. M., 2013. Loan growth and bank risk: New evidence. Financial Markets and Portfolio Management, 27(4), pp. 365-379. Anzoategui, D., Rocha, R. \& Martinez Peria, M. S., 2010. Bank Competition In The Middle East And Northern Africa Region, s.1.: Policy Research Working Paper 5363, World Bank.

Baltagi, B. H., Bresson, G. \& Pirotte, A., 2003. F ixed effects, random effects or Hausman-Taylor? A pretest estimator. Economics Letters, Volume 79, p. 361-369.

Barry, T. A., Lepetit, L. \& Tarazi, A., 2011. Ownership structure and risk in publicly held and privately owned banks. Journal of Banking \& Finance, 35(5), p. 1327-1340.

Beck, T., De Jonghe, O. \& Schepens, G., 2013. Bank competition and stability: Crosscountry heterogeneity. Journal of Financial Intermediation, 22(2), p. 218-244.

Beck, T., Demirgüç-Kunt, A. \& Levine, . R., 2006. Bank concentration, competition, and crises: First results. Journal of Banking \& Finance, 30(5), p. 1581-1603.

Beck, T., Demirgüç-Kunt, A. \& Levine, R., 2006. Bank supervision and corruption in lending. Journal of Monetary Economics, 53(8), p. 2131-2163.

Beck, T., Demirgüç-Kunt, A. \& Levine, R., 2009. Financial Institutions and Markets

Financial Institutions and Markets - Data and Analysis, s.1.: World Bank Policy Research Working Paper 4943.

Beck, T. \& Laeven, L., 2006. Resolution of failed banks by deposit insurers: Crosscountry evidence. World Bank policy research working paper (3920).

Ben Naceur, S., Ben-Khedhiri, H. \& Casu, B., 2011. What Drives the Performance of Selected MENA Banks? A Meta-Frontier Analysis. IMF Working Paper No. 11/34.

Białkowski, J., Gottschalk, K. \& Wisniewski, T. P., 2008. Stock market volatility around national elections. Journal of Banking \& Finance, 32(9), p. 1941-1953.

Bourgain, A., Pieretti, P. \& Zanaj, S., 2012. Financial openness, disclosure and bank risktaking in MENA countries. Emerging Markets Review, 13(3), pp. 283-300.

Bourgain, A., Pieretti, P. \& Zanaj, . S., 2012. Financial openness, disclosure and bank risk-taking in MENA countries. Emerging Markets Review, 13(3), p. 283-300.

Bourkhis, K. \& Nabi, . M. S., 2013. Islamic and conventional banks' soundness during the 2007-2008 financial crisis. Review of Financial Economics, 22(2), p. 68-77.

Bouvatier, V., 2014. Heterogeneous bank regulatory standards and the cross-border supply of financial services. Economic Modelling, Volume 40, p. 342-354.

Bouvatier, V., Lepetit, L. \& Strobel, F., 2014. Bank income smoothing, ownership concentration and the regulatory environment. Journal of Banking \& Finance, Volume 41, p. 253-270. 
Bouvatier, V., Lepetit, . L. \& Strobel, . F., 2014. Bank income smoothing, ownership concentration and the regulatory environment. Journal of Banking \& Finance, Volume 41, p. 253-270.

Boyd, J. H., De Nicolò, G. \& Jalal, A. M., 2007. Bank Risk-Taking and Competition Revisited: New Theory and New Evidence, s.l.: IMF Working Paper WP/06/297. Boyd, J. H., De Nicolò, G. \& Jalal, A. M., 2006. Bank Risk-Taking and Competition Revisited: New Theory and New Evidence, s.l.: IMF Woking Paper 06/297.

Boyd, J. H. \& Runkle, D. E., 1993. Size and performance of banking firms: Testing the predictions of theory. Journal of Monetary Economics, 31(1), p. 47-67.

Bremus, F. M. \& , 2015. Cross-border banking, bank market structures and market power: Theory and cross-country evidence. Journal of Banking \& Finance, Volume 50, p. 242-259.

Breusch, T., Ward, M. B., Nguyen, H. T. M. \& Kompa, T., 2011. FEVD: Just IV or Just Mistaken?. Political Analysis, 19(2), pp. 165-169.

Breusch, T., Ward, M. B., Nguyen, H. T. M. \& Kompa, T., 2011. On the Fixed-Effects Vector Decomposition. Political Analysis, 19(2), pp. 123-134.

Cetorellia, N. \& Goldberg, L. S., 2012. Liquidity management of U.S. global banks: Internal capital markets in the great recession. Journal of International Economics, 88(2), p. 299-311.

Charles, A. \& Olivier, D., 2014. Large shocks in the volatility of the Dow Jones Industrial Average index: 1928-2013. Journal of Banking \& Finance, Volume 43, p. 188-199.

Chau, F., Deesomsak, R. \& Wang, J., 2014. Political uncertainty and stock market volatility in the Middle East and North African (MENA) countries. Journal of International Financial Markets, Institutions \& Money, Volume 28, pp. 1 - 19.

Chen, P.-F. \& Liu, P.-C., 2013. Bank ownership, performance, and the politics: Evidence from Taiwan. Economic Modelling, Volume 31, p. 578-585.

Chiorazzo, V., Milani, C. \& Salvini, F., 2008. Income Diversification and Bank

Performance: Evidence from Italian Banks. Journal of Financial Services Research, 33(3), pp. 181-203.

Čihák, M. \& Hesse, H., 2010. Islamic banks and financial stability: an empirical analysis. Journal of Financial Services Research, 38(2), pp. 95-113.

Claessens, S., 2006. Competitive Implications of Cross-Border Banking, s.l.: World Bank Policy Research Working Paper WPS3854.

Council on Foreign Relations, 2011. The New Arab Revolt, New York: Council on Foreign Relations / Foreign Affaires.

De Jonghe, O., 2010. Back to the basics in banking? A micro-analysis of banking system stability. Journal of Financial Intermediation, 19(3), p. 387-417.

De Nicoló, G. \& Loukoianova, E., 2007. Bank Ownership, Market Structure and Risk, s.l.: IMF Working Paper 215, International Monetary Fund.

Demirgüç-Kunt, A. \& Detragiache, E., 2002. Does deposit insurance increase banking system stability? An empirical investigation. Journal of Monetary Economics, 49(7), p. 1373-1406.

Demirgüç-Kunt, A., Detragiache, E. \& Tressel, T., 2006. Banking On The Principles : Compliance With Basel Core Principles And Bank Soundness, s.l.: Policy Research Working Paper 3954, World Bank . 
Demirguc-Kunt, A. \& Huizinga, H., 2010. Bank activity and funding strategies: The impact on risk and returns. Journal of Financial Economics, Volume 98, p. 626-650. Demirgüç-Kunt, A. \& Huizinga, H., 2013. Are banks too big to fail or too big to save? International evidence from equity prices and CDS spreads. Journal of Banking \& Finance, 37(3), p. 875-894.

Deng, S. (., Elyasiani, . E. \& Mao, . C. X., 2007. Diversification and the cost of debt of bank holding companies. Journal of Banking \& Finance, 31(8), p. 2453-2473.

DeYoung, R. \& Torna, . G., 2013. Nontraditional banking activities and bank failures during the financial crisis. Journal of Financial Intermediation, 22(3), p. 397-421. Dong, Y., Meng, . C., Firth, . M. \& Hou, W., 2014. Ownership structure and risk-taking: Comparative evidence from private and state-controlled banks in China. International Review of Financial Analysis, http://dx.doi.org/10.1016/j.irfa.2014.03.009.

Foos, D., Norden, L. \& Weber, M., 2010. Loan growth and riskiness of banks. Journal of Banking \& Finance, 34(12), p. 2929-2940.

Francis, B. B., Hasan, I. \& Zhu, Y., 2014. Political uncertainty and bank loan contracting. Journal of Empirical Finance, Volume 29, pp. 281-286.

FSI-BIS, 2012. Financial Stability Institute (FSI) Survey on Basel II, 2.5 and III Implementation, s.l.: Bank for International Settlements.

FSI-BIS, 2014. Financial Stability Institute (FSI) Survey on Basel II, 2.5 and III Implementation, s.1.: Bank for International Settlements.

Fu, X. (., Lin, Y. (. \& Molyneux, P., 2014. Bank competition and financial stability in Asia Pacific. Journal of Banking \& Finance, Volume 38, p. 64-77.

Gallo, J. G., Apilado, . V. P. \& Kolari, . J. W., 1996. Commercial bank mutual fund activities: Implications for bank risk and profitability. Journal of Banking \& Finance, 20(10), p. 1775-1791.

García-Marco, T. \& Robles-Fernández, . M. D., 2008. Risk-taking behaviour and ownership in the banking industry: The Spanish evidence. Journal of Economics and Business, 60(4), p. 332-354.

Ghosh , S., 2015. Political transition and bank performance: How important was the Arab Spring?. Journal of Comparative Economics, Volume http://dx.doi.org/10.1016/j.jce.2015.02.001.

Goodell, J. W. \& Vähämaa, S., 2013. US presidential elections and implied volatility: The role of political uncertainty. Journal of Banking \& Finance, 37(3), p. 1108-1117. Gorton, G. \& Rosen, R., 1995. Portfolio Choice, and the Decline of Banking. The Journal of Finance, 50(5), pp. 1377-1420.

Goyeau, D. \& Tarazi, A., 1992. Evaluation du risqué de défaillance bancaire en Europe. Revue, Volume 102, pp. 249-280.

Greene, W., 2011. Fixed Effects Vector Decomposition: A Magical Solution to the Problem of Time-Invariant Variables in Fixed Effects Models?. Political Analysis, 19(2), pp. 135-146.

Guyot, A., Lagoarde-Segot, T. \& Neaime, S., 2014. Foreign shocks and international cost of equity destabilization. Evidence from the MENA region. Emerging Markets Review, Volume 18, p. 101-122.

Hausman, J. A. \& Taylor, W. E., 1981. Panel data and unobservable individual effects. Econometrica, 49(6), pp. 1377-1398. 
Haw, I.-M., Ho, . S. S., Hu, B. \& Wu, D., 2010. Concentrated control, institutions, and banking sector: An international study. Journal of Banking \& Finance, 34(3), p. 485497.

Hellman, T., Murdock, K. \& Joseph , E. S., 2000. Liberalization, moral hazard in banking and prudential regulation: Are capital controls enough?. American Economic Review, 90(1), pp. 147-165.

Hsieh, M.-F., Chen, P.-F., Lee , C.-C. \& Yang, S.-J., 2013. How Does Diversification Impact Bank Stability? The Role of Globalization, Regulations, and Governance Environments. Asia-Pacific Journal of Financial Studies , 42(5), p. 813-844.

Iannotta, G., Nocera, G. \& Sironi, A., 2007. Ownership structure, risk and performance in the European banking industry. Journal of Banking \& Finance, 31(7), p. 2127-2149.

Iannotta, G., Nocera, . G. \& Sironi, . A., 2013. The impact of government ownership on bank risk. Journal of Financial Intermediation, 22(2), p. 152-176.

Iannotta, G., Nocera, . G. \& Sironi, A., 2013. The impact of government ownership on bank risk. Journal of Financial Intermediation, 22(2), p. 152-176.

Imbierowicz, B. \& Rauch, C., 2014. The relationship between liquidity risk and credit risk in banks. Journal of Banking and Finance, 40(1), pp. 242-256.

Jeon, B. N., Olivero, M. P. \& Ji, W., 2011. Do foreign banks increase competition?

Evidence from emerging Asian and Latin American banking markets. Journal of Banking \& Finance, 35(4), p. 856-875.

Jeon, B. N., Olivero, M. P. \& Ji, W., 2013. Multinational banking and the international transmission of financial shocks: Evidence from foreign bank subsidiaries. Journal of Banking \& Finance, 37(3), p. 952-972.

Julio, B. \& Yook, Y., 2012. Political uncertainty and corporate investment cycles. Journal of Finance, 67(1), pp. 45-84.

Khandelwal, P. \& Roitman, A., 2013. The Economics of Political Transitions: Implications for the Arab Spring. IMF Working Paper.

Köhler, M., 2014. Which banks are more risky? The impact of business models on bank stability. Journal of Financial Stability, http://dx.doi.org/10.1016/j.jfs.2014.02.005.

Kwan, S. H. \& Laderman, E. S., 1999. On the portfolio effects of financial convergence: a review of the literature. Federal Reserve Bank of San Francisco, Volume 2, p. 18-31. Laeven, L. \& Levine, R., 2009. Bank governance, regulation and risk taking. Journal of Financial Economics, 93(2), p. 259-275.

Lepetit, L., Nys, . E., Rous, . P. \& Tarazi, A., 2008. Bank income structure and risk: An empirical analysis of European banks. Journal of Banking \& Finance, 32(8), p. 14521467.

Lepetit, L., Nys, . E., Rous, P. \& Tarazi, A., 2008. Bank income structure and risk: An empirical analysis of European banks. Journal of Banking \& Finance, 32(8), p. 14521467.

Liu, W.-M. \& Ngo, P. T., 2014. Elections, political competition and bank failure. Journal of Financial Economics, 112(2), p. 251-268.

Love, I. \& Ariss, R. T., 2014. Macro-financial linkages in Egypt: A panel analysis of economic shocks and loan portfolio quality. Journal of International Financial Markets, Institutions and Money, Volume 28, p. 158-181. 
Maghyereh, A. I. \& Awartani, B., 2014. Bank distress prediction: Empirical evidence from the Gulf Cooperation Council countries. Research in International Business and Finance, Volume 30, p. 126-147.

Malik, A. \& Awadallah, B., 2013. The Economics of the Arab Spring. World Development, Volume 45, p. 296-313.

Mati, M. E. A., 2008. Crises: Fundementals and Patterns of Contagion. s.1.:George Washington University (ProQuest).

Matutes , C. \& Vives, X., 2000. Imperfect competition, risk taking and regulation in banking. European Economic Review, Volume 44, pp. 1-34.

Neaime, S., 2012. The global financial crisis, financial linkages and correlations in returns and volatilities in emerging MENA stock markets. Emerging Markets Review, 13(3), p. 268-282.

Olson, D. \& Zoubi, T. A., 2011. Efficiency and bank profitability in MENA countries. Emerging Markets Review, 12(2), pp. 94-110.

Önder, Z. \& Özyıldırım, S., 2013. Role of bank credit on local growth: Do politics and crisis matter?. Journal of Financial Stability, 9(1), p. 13-25.

Pástor, L. \& Veronesi, P., 2013. Political uncertainty and risk premia. Journal of Financial Economics, 110(3), p. 520-545.

Plümper, T. \& Troeger, V. E., 2007. Efficient Estimation of Time-Invariant and Rarely Changing Variables in Finite Sample Panel Analyses with Unit Fixed Effects. Political Analysis, 15(2), pp. 124-139.

Popov, A. \& Udell, G. F., 2012. Cross-border banking, credit access, and the financial crisis. Journal of International Economics, 87(1), p. 147-161.

Rajan, R. G., Servaes, H. \& Zingales, L., 2000. The cost of diversity: the diversification discount and inefficient investment. Journal of Finance, 55(1), pp. 35-80.

Saeed, M. \& Izzeldin, M., 2014. Examining the relationship between default risk and efficiency in Islamic and conventional banks. Journal of Economic Behavior \& Organization, p. http://dx.doi.org/10.1016/j.jebo.2014.02.014.

Saghi-Zedek, N. \& Tarazi, A., 2014. Excess control rights, financial crisis and bank profitability and risk. Journal of Banking \& Finance, pp. article in press, http://dx.doi.org/10.1016/j.jbankfin.2014.10.011.

Sanya, S. \& Wolfe, S., 2011. Can Banks in Emerging Economies Benefit from Revenue Diversification?. Journal of Financial Services Research, 40(1), pp. 79-101.

Saunders, A., Strock , E. \& Travlos, N. G., 1990. Ownership Structure, Deregulation, and Bank Risk Taking. The Journal of Finance, 45(2), pp. 643-654.

Shehzad, C. T., de Haan, J. \& Scholtens, B., 2010. The impact of bank ownership concentration on impaired loans and capital adequacy. Journal of Banking \& Finance, 34(2), p. 399-408.

Shiers, A. F., 2002. Branch banking, economic diversity and bank risk. The Quarterly Review of Economics and Finance, 42(3), p. 587-598.

Soedarmono, W. \& Tarazi, A., 2013. Bank opacity, intermediation cost and globalization: Evidence from a sample of publicly traded banks in Asia. Journal of Asian Economics, Volume 29, p. 91-100.

Srairi, S., 2013. Ownership structure and risk-taking behaviour in conventional and Islamic banks: Evidence for MENA countries. Borsa Istanbul Review, 13(4), p. 115-127. 
Stiroh, . K. J., 2006. New evidence on the determinants of bank risk. Journal of Financial Service Research, Volume 30, p. 237-263.

Stiroh, K. J. \& Rumble, . A., 2006. The dark side of diversification: The case of US financial holding companies. Journal of Banking \& Finance, 30(8), p. 2131-2161.

Tabak, B. M., Fazio, D. M. \& Cajueiro, D. O., 2013. Systemically important banks and financial stability: The case of Latin America. Journal of Banking \& Finance, 37(10), p. 3855-3866.

Tang, C. F. \& Abosedra, S., 2014. The impacts of tourism, energy consumption and political instability on economic growth in the MENA countries. Energy Policy, Volume 68 , p. $458-464$.

Turk-Ariss, R., 2009. Competitive behavior in Middle East and North Africa banking systems. The Quarterly Review of Economics and Finance, Volume 49, pp. 693-710. Uhde, A. \& Heimeshoff, U., 2009. Consolidation in banking and financial stability in Europe: Empirical evidence. Journal of Banking \& Finance, 33(7), p. 1299-1311. Vaugirard, V., 2007. Bank bailouts and political instability. European Journal of Political Economy, Volume 23, p. 821-837.

Wagner, W., 2007. The liquidity of bank assets and banking stability. Journal of Banking \& Finance, 31(1), p. 121-139.

Wagner, W., 2010. Diversification at financial institutions and systemic crises. Journal of Financial Intermediation, 19(3), p. 373-386.

Wu, J., Luca, A. C. \& Jeon, B. N., 2011. Foreign bank penetration and the lending channel in emerging economies: Evidence from bank-level panel data. Journal of International Money and Finance, 30(6), p. 1128-1156. 


\begin{tabular}{|c|c|c|c|c|c|c|}
\hline Country & $\begin{array}{l}\text { Loans To } \\
\text { Deposits }\end{array}$ & $\begin{array}{l}\text { Overheads } \\
\text { To Total } \\
\text { Assets }\end{array}$ & $\begin{array}{l}\text { Net } \\
\text { Interest } \\
\text { Margin }\end{array}$ & Concentration & ROA & Z-Score \\
\hline $\begin{array}{l}\text { United Arab } \\
\text { Emirates }\end{array}$ & 104,44 & 1,28 & 3,23 & 60,89 & 1,57 & 21,66 \\
\hline Bahrain & 98,65 & 1,10 & 2,14 & 89,06 & 1,16 & 17,57 \\
\hline Djibouti & 42,85 & 3,90 & 2,86 & & 1,00 & 9,89 \\
\hline Algeria & 31,80 & 1,18 & 2,24 & 75,50 & 1,63 & 21,49 \\
\hline Egypt & 49,54 & 1,62 & 2,50 & 60,75 & 0,75 & 39,54 \\
\hline Iran & 93,84 & & & & & \\
\hline Iraq & 25,60 & 2,53 & 4,19 & 87,04 & 3,28 & 25,33 \\
\hline Israel & 99,91 & 2,21 & 2,49 & 79,93 & 0,71 & 24,81 \\
\hline Jordan & 73,25 & 1,70 & 3,15 & 88,22 & 1,14 & 44,58 \\
\hline Kuwait & 96,72 & 1,16 & 3,07 & 88,95 & 1,48 & 19,10 \\
\hline Lebanon & 36,24 & 1,37 & 2,02 & 51,30 & 0,94 & 50,01 \\
\hline Libya & 21,19 & 0,16 & 0,03 & & $-0,04$ & 31,09 \\
\hline Morocco & 80,06 & 1,96 & 2,62 & 71,19 & 1,19 & 30,59 \\
\hline Malta & 87,98 & 1,62 & 2,65 & 87,12 & 0,54 & 13,79 \\
\hline Oman & 120,25 & 1,99 & 3,39 & 72,95 & 1,39 & 12,07 \\
\hline Qatar & 80,13 & 0,94 & 3,31 & 86,88 & 2,68 & 27,62 \\
\hline Saudi Arabia & 133,75 & 1,38 & 2,84 & 55,33 & 1,99 & 14,68 \\
\hline Syria & & 1,44 & 2,53 & 75,45 & 0,45 & 8,54 \\
\hline Tunisia & 131,26 & 2,12 & 2,80 & 41,07 & 0,41 & 21,89 \\
\hline Palestine & 40,50 & 2,97 & 4,58 & & 1,95 & 17,94 \\
\hline Yemen & 27,02 & 2,06 & 4,20 & & 1,34 & 30,01 \\
\hline $\begin{array}{l}\text { MENA } \\
\text { average }\end{array}$ & 73,75 & 1,73 & 2,84 & 73,23 & 1,28 & 24,11 \\
\hline $\begin{array}{l}\text { OECD } \\
\text { average }\end{array}$ & 117,45 & 1,43 & 1,99 & 70,91 & 0,38 & 13,47 \\
\hline
\end{tabular}

Source: World Bank Financial Development and Structure Dataset (November 2013).

All stated figures are percentages.

Concentration: Assets of three largest banks as a share of assets of all commercial banks. ROA: Average

Return on Assets (Net Income/Total Assets). Z-Score: estimated as (ROA+equity/assets)/sd(ROA);

$\operatorname{sd}(\mathrm{ROA})$ is the standard deviation of ROA. 
Table 2 Descriptive statistics

\begin{tabular}{l|lllll} 
& Obs & Mean & Std. Dev. & Min & Max \\
\hline Z-Score & 2128 & 3.595898 & 1.165328 & 0.079596 & 7.745494 \\
FS & 2904 & 2.321281 & 6.447254 & 0 & 74 \\
ASdate & 3024 & 0.222222 & 0.415809 & 0 & 1 \\
GOBs & 2781 & 17.70683 & 32.43499 & 0 & 100 \\
Islamic & 3024 & 0.267857 & 0.442916 & 0 & 1 \\
Window & 3024 & 0.110119 & 0.31309 & 0 & 1 \\
OC & 2718 & 52.71805 & 31.00297 & 5.55 & 100 \\
CAR & 2162 & 0.150908 & 0.106388 & 0.045281 & 0.649736 \\
NPL & 1349 & 9.62894 & 13.33359 & 0 & 83.2 \\
Size & 2412 & 14.61052 & 1.66372 & 10.6929 & 18.05852 \\
Divers & 2198 & 0.586992 & 0.237547 & 0 & 0.98977 \\
HHI & 2984 & 0.186638 & 0.109391 & 0.086634 & 0.678922 \\
GGL & 2115 & 21.95648 & 38.14225 & -58.8 & 327.82 \\
GDP & 2807 & 8.957581 & 1.110829 & 6.56103 & 10.9398 \\
GDP_Growth & 2858 & 5.150745 & 3.226483 & -5.84 & 17.99 \\
FI_Growth & 2930 & 0.287495 & 1.607285 & -6.8 & 12.85
\end{tabular}

ASdate, Islamic, and Window are dummy variables that take the value of with one or zero. FS is a continuous variable. Z-score, Size, and GDP are natural logarithm of the actual value. HHI ranges between 0 and 1 . Remaining variables are percentages.

$\mathrm{Z}$-score $=$ Natural logarithm of Z-score, a measure of stability. FS continuous variable representing the actual number of foreign subsidiaries owned by each bank. Aspring, ASdate, Islamic, and Window= dummy variables that take the value of one if country is directly affected by the 'Arab Spring' during 2011 and 2012, if the date in 2011 or 2012, if the bank is considered Islamic, and if the bank is conventional with an Islamic window, respectively, or zero otherwise. GOBs: percentage of bank ownership held by governmental institutes. OC: percentage of the highest shareholder shares. $\mathrm{CAR}=$ the ratio of equity to total assets. NPL: ratio of impaired loans to total loans. Size: natural logarithm of assets. Divers= 1- | (net interest revenue - other operating income) / operating income|. HHI= Herfindhal-Hirschman index, a measure of market concentration. GGL: growth of gross loans. GDP: natural logarithm of GDP per capita. GDP_Growth: annual growth rate of GDP per capita. FI_growth: annual growth rate of foreign investments. 
Table 3 Distribution of Foreign Subsidiaries over regions

\begin{tabular}{lcccccccc} 
& Africa & $\begin{array}{c}\text { South } \\
\text { America }\end{array}$ & Asia & Australia & Europe & MENA & USA & Total \\
\hline Algeria & 0 & 0 & 0 & 0 & 4 & 1 & 0 & 5 \\
\hline Bahrain & 7 & 26 & 14 & 2 & 28 & 62 & 28 & 167 \\
\hline Djibouti & 0 & 0 & 0 & 0 & 0 & 0 & 0 & 0 \\
\hline Egypt & 1 & 0 & 1 & 0 & 5 & 7 & 0 & 14 \\
\hline Iraq & 0 & 0 & 0 & 0 & 0 & 6 & 0 & 6 \\
\hline Iran & 0 & 0 & 0 & 0 & 10 & 2 & 0 & 12 \\
\hline Israel & 0 & 2 & 0 & 0 & 24 & 0 & 7 & 33 \\
\hline Jordan & 0 & 0 & 0 & 1 & 4 & 24 & 0 & 29 \\
\hline Kuwait & 0 & 12 & 7 & 0 & 25 & 56 & 2 & 102 \\
\hline Lebanon & 4 & 1 & 0 & 2 & 26 & 38 & 0 & 71 \\
\hline Libya & 8 & 1 & 0 & 0 & 5 & 14 & 0 & 28 \\
\hline Malta & 0 & 0 & 0 & 0 & 2 & 0 & 0 & 2 \\
\hline Morocco & 18 & 1 & 1 & 0 & 19 & 3 & 0 & 42 \\
\hline Oman & 4 & 0 & 8 & 0 & 2 & 5 & 0 & 19 \\
\hline Palestine & 0 & 0 & 0 & 0 & 0 & 1 & 0 & 1 \\
\hline Qatar & 3 & 17 & 9 & 0 & 14 & 29 & 0 & 72 \\
\hline Saudi Arabia & 0 & 1 & 7 & 0 & 3 & 24 & 0 & 35 \\
\hline Syria & 0 & 0 & 0 & 0 & 0 & 2 & 0 & 2 \\
\hline Tunisia & 0 & 0 & 0 & 0 & 1 & 3 & 0 & 4 \\
\hline Uae & 0 & 28 & 13 & 0 & 33 & 32 & 2 & 108 \\
\hline Yemen & 0 & 0 & 1 & 0 & 0 & 3 & 0 & 4 \\
\hline Total & 45 & 89 & 61 & 5 & 205 & 312 & 39 & 756 \\
\hline
\end{tabular}


Table 4 List of banks operating in one or more regions

\begin{tabular}{lccc} 
& 1 region & 2 regions & 3 or more regions \\
\hline Algeria & 2 & 1 & 0 \\
\hline Bahrain & 8 & 6 & 8 \\
\hline Djibouti & 0 & 0 & 0 \\
\hline Egypt & 3 & 2 & 1 \\
\hline Iraq & 5 & 0 & 0 \\
\hline Iran & 2 & 2 & 0 \\
\hline Israel & 0 & 3 & 1 \\
\hline Jordan & 4 & 1 & 1 \\
\hline Kuwait & 4 & 4 & 3 \\
\hline Lebanon & 3 & 7 & 3 \\
\hline Libya & 0 & 0 & 1 \\
\hline Malta & 2 & 0 & 0 \\
\hline Morocco & 1 & 2 & 1 \\
\hline Oman & 3 & 0 & 1 \\
\hline Palestine & 1 & 0 & 0 \\
\hline Qatar & 2 & 1 & 5 \\
\hline Saudi Arabia & 4 & 3 & 2 \\
\hline Syria & 2 & 0 & 0 \\
\hline Tunisia & 3 & 0 & 0 \\
\hline UAE & 7 & 4 & 5 \\
\hline Yemen & 0 & 1 & 0 \\
\hline Total & 56 & 37 & 32 \\
\hline & & & 0 \\
\hline
\end{tabular}


Table 5 correlation matrix

\begin{tabular}{|c|c|c|c|c|c|c|c|c|c|c|c|c|c|c|c|c|}
\hline & Z-Score & FS & ASdate & Public & Islamic & Window & $O C$ & CAR & NPL & Size & Divers & HHI & GGL & GDP & $\begin{array}{l}\text { GDP } \\
\text { Grouth }\end{array}$ & $\begin{array}{c}\text { FI } \\
\text { Grouth }\end{array}$ \\
\hline Z-Score & 1 & & & & & & & & & & & & & & & \\
\hline FS & -0.037 & 1 & & & & & & & & & & & & & & \\
\hline ASdate & 0.1391 & -0.0294 & 1 & & & & & & & & & & & & & \\
\hline Public & -0.0843 & 0.2908 & 0.0121 & 1 & & & & & & & & & & & & \\
\hline Islamic & -0.1727 & 0.0772 & 0.05 & -0.005 & 1 & & & & & & & & & & & \\
\hline Window & -0.0773 & 0.1334 & -0.0512 & 0.2562 & -0.2121 & 1 & & & & & & & & & & \\
\hline OC & -0.0016 & -0.0489 & 0.0582 & 0.0622 & -0.083 & -0.0342 & 1 & & & & & & & & & \\
\hline CAR & -0.0682 & -0.0733 & 0.0621 & 0.095 & 0.2252 & 0.0138 & -0.1503 & 1 & & & & & & & & \\
\hline NPL & -0.1184 & -0.115 & 0.012 & -0.0983 & -0.0497 & -0.0908 & 0.1055 & 0.0135 & 1 & & & & & & & \\
\hline Size & -0.0012 & 0.4193 & 0.0929 & 0.2703 & -0.024 & 0.3513 & -0.1825 & -0.2364 & -0.3968 & 1 & & & & & & \\
\hline Divers & -0.138 & 0.0435 & -0.1282 & 0.046 & -0.0672 & 0.0316 & -0.0072 & -0.0874 & -0.0754 & 0.1547 & 1 & & & & & \\
\hline HHI & -0.001 & -0.0234 & -0.0088 & -0.094 & -0.0735 & -0.2401 & -0.0071 & -0.0202 & -0.0907 & -0.1227 & -0.0157 & 1 & & & & \\
\hline GGL & -0.1138 & -0.0269 & -0.098 & 0.0387 & 0.1667 & -0.021 & -0.0584 & 0.1782 & -0.1225 & -0.0786 & 0.0803 & -0.0302 & 1 & & & \\
\hline GDP & -0.0803 & 0.0881 & 0.0714 & 0.1501 & 0.0823 & 0.228 & -0.0643 & 0.1874 & -0.3056 & 0.4225 & 0.0722 & -0.1146 & 0.0721 & 1 & & \\
\hline GDP Grouth & 0.0641 & 0.0186 & -0.2511 & -0.0373 & -0.0791 & 0.0662 & -0.0885 & -0.0142 & 0.0047 & -0.0199 & 0.12 & -0.0078 & 0.1605 & -0.0375 & 1 & \\
\hline FI Grouth & $\mid-0.0027$ & 0.0029 & -0.1087 & 0.0324 & -0.0321 & -0.0176 & -0.0513 & 0.0609 & -0.0393 & 0.031 & 0.097 & 0.0745 & 0.0171 & 0.1622 & 0.1654 & 1 \\
\hline
\end{tabular}

Z-score: Natural logarithm of Z-score, a measure of stability. FS: continuous variable representing the actual number of foreign subsidiaries owned by each bank. ASdate, Islamic, and Window= dummy variables that take the value of one if the date is 2011 or 2012, if the bank is considered Islamic, and if the bank is conventional with an Islamic window, respectively, or zero otherwise. GOBs: percentage of bank ownership held by governmental institutes. OC: percentage of the highest shareholder shares. CAR = the ratio of equity to total assets. NPL: ratio of impaired loans to total loans. Size: natural logarithm of assets. Divers = 1| (net interest revenue - other operating income) / operating income|. HHI= Herfindhal-Hirschman index, a measure of market concentration. GGL: growth of gross loans. GDP: natural logarithm of GDP per capita. GDP_Growth: annual growth rate of GDP per capita. FI_growth: annual growth rate of foreign investments. 
Table 6 MENA banks stability and the effects of the 'Arab Spring' and the Global Financial Crisis (Hausman Taylor model).

\begin{tabular}{|c|c|c|c|c|c|c|}
\hline & $\begin{array}{c}\text { Z-score } \\
1\end{array}$ & $\begin{array}{c}Z 1 \\
2\end{array}$ & $\begin{array}{c}\mathrm{Z2} \\
3\end{array}$ & $\begin{array}{c}\text { Z-score } \\
4\end{array}$ & $\begin{array}{c}\mathrm{Z1} \\
5\end{array}$ & $\begin{array}{c}\mathrm{Z2} \\
6\end{array}$ \\
\hline ASdate & $\begin{array}{l}0.451^{* * *} \\
(5.6600)\end{array}$ & $\begin{array}{c}0.146 \\
(1.6000)\end{array}$ & $\begin{array}{l}0.459^{* * *} \\
(5.8900)\end{array}$ & & & \\
\hline GFC & & & & $\begin{array}{c}-0.324^{* * *} \\
(-5.09)\end{array}$ & $\begin{array}{c}-0.199^{* * *} \\
(-2.77)\end{array}$ & $\begin{array}{c}-0.329^{* * *} \\
(-5.28)\end{array}$ \\
\hline FS & $\begin{array}{l}-0.314^{* *} \\
(-2.06)\end{array}$ & $\begin{array}{l}-0.122 \\
(-0.60)\end{array}$ & $\begin{array}{l}-0.228^{*} \\
(-1.72)\end{array}$ & $\begin{array}{c}-0.471^{* * *} \\
(-2.79)\end{array}$ & $\begin{array}{l}-0.199 \\
(-1.02)\end{array}$ & $\begin{array}{l}-0.365^{* *} \\
(-2.38)\end{array}$ \\
\hline GOBs & $\begin{array}{c}0.002 \\
(0.6700)\end{array}$ & $\begin{array}{c}-0.00345 \\
(-0.97)\end{array}$ & $\begin{array}{l}0.00131 \\
(0.4800)\end{array}$ & $\begin{array}{c}0.000959 \\
(0.3300)\end{array}$ & $\begin{array}{c}-0.00377 \\
(-1.10)\end{array}$ & $\begin{array}{c}0.000228 \\
(0.0900)\end{array}$ \\
\hline Islamic & $\begin{array}{l}-0.264 \\
(-1.24)\end{array}$ & $\begin{array}{c}-0.754^{* * *} \\
(-2.96)\end{array}$ & $\begin{array}{l}-0.256 \\
(-1.31)\end{array}$ & $\begin{array}{l}-0.215 \\
(-1.04)\end{array}$ & $\begin{array}{c}-0.728^{* * *} \\
(-2.96)\end{array}$ & $\begin{array}{l}-0.21 \\
(-1.13)\end{array}$ \\
\hline Window & $\begin{array}{c}0.0255 \\
(0.1100)\end{array}$ & $\begin{array}{l}-0.0519 \\
(-0.19)\end{array}$ & $\begin{array}{c}-0.0503 \\
(-0.24)\end{array}$ & $\begin{array}{l}-0.102 \\
(-0.46)\end{array}$ & $\begin{array}{c}-0.0948 \\
(-0.36)\end{array}$ & $\begin{array}{l}-0.176 \\
(-0.89)\end{array}$ \\
\hline OC & $\begin{array}{c}-0.00636^{* *} \\
(-2.27)\end{array}$ & $\begin{array}{c}-0.00122 \\
(-0.36)\end{array}$ & $\begin{array}{c}-0.00542^{* *} \\
(-2.05)\end{array}$ & $\begin{array}{c}-0.00525^{*} \\
(-1.92)\end{array}$ & $\begin{array}{c}-0.000842 \\
(-0.25)\end{array}$ & $\begin{array}{c}-0.00428^{*} \\
(-1.71)\end{array}$ \\
\hline CAR & $\begin{array}{c}0.123 \\
(0.1100)\end{array}$ & $\begin{array}{c}1.802 \\
(1.2100)\end{array}$ & $\begin{array}{c}1.48 \\
(1.1400)\end{array}$ & $\begin{array}{c}0.468 \\
(0.4100)\end{array}$ & $\begin{array}{c}2.088 \\
(1.4300)\end{array}$ & $\begin{array}{c}1.927 \\
(1.5000)\end{array}$ \\
\hline NPL & $\begin{array}{c}-0.00802 \\
(-1.47)\end{array}$ & $\begin{array}{c}-0.0135^{* *} \\
(-2.07)\end{array}$ & $\begin{array}{c}-0.00565 \\
(-1.05)\end{array}$ & $\begin{array}{c}-0.0071 \\
(-1.30)\end{array}$ & $\begin{array}{c}-0.0142^{* *} \\
(-2.17)\end{array}$ & $\begin{array}{c}-0.00402 \\
(-0.74)\end{array}$ \\
\hline SIZE & $\begin{array}{c}0.0572 \\
(0.5500)\end{array}$ & $\begin{array}{c}0.129 \\
(1.1100)\end{array}$ & $\begin{array}{c}0.0597 \\
(0.6100)\end{array}$ & $\begin{array}{l}0.206^{* *} \\
(2.0400)\end{array}$ & $\begin{array}{c}0.198^{*} \\
(1.7600)\end{array}$ & $\begin{array}{l}0.199^{* *} \\
(2.1000)\end{array}$ \\
\hline Divers & $\begin{array}{l}-0.312 \\
(-1.61)\end{array}$ & $\begin{array}{l}-0.253 \\
(-1.11)\end{array}$ & $\begin{array}{l}-0.363^{*} \\
(-1.91)\end{array}$ & $\begin{array}{l}-0.457^{* *} \\
(-2.36)\end{array}$ & $\begin{array}{l}-0.306 \\
(-1.35)\end{array}$ & $\begin{array}{c}-0.516^{* * *} \\
(-2.73)\end{array}$ \\
\hline $\mathrm{HHI}$ & $\begin{array}{c}1.401 \\
(0.7300)\end{array}$ & $\begin{array}{c}1.313 \\
(0.6000)\end{array}$ & $\begin{array}{c}1.535 \\
(0.8100)\end{array}$ & $\begin{array}{c}2.498 \\
(1.2900)\end{array}$ & $\begin{array}{c}1.904 \\
(0.8700)\end{array}$ & $\begin{array}{c}2.746 \\
(1.4400)\end{array}$ \\
\hline GGL & $\begin{array}{c}-0.00447^{* * *} \\
(-3.22)\end{array}$ & $\begin{array}{c}-0.00395^{* *} \\
(-2.41)\end{array}$ & $\begin{array}{c}-0.00448^{* * *} \\
(-3.20)\end{array}$ & $\begin{array}{c}-0.00510^{* * *} \\
(-3.66)\end{array}$ & $\begin{array}{c}-0.00419^{* * *} \\
(-2.58)\end{array}$ & $\begin{array}{c}-0.00499^{* * *} \\
(-3.55)\end{array}$ \\
\hline GDP & $\begin{array}{c}-0.00299 \\
(-0.02)\end{array}$ & $\begin{array}{c}-0.0091 \\
(-0.04)\end{array}$ & $\begin{array}{c}-0.00588 \\
(-0.03)\end{array}$ & $\begin{array}{l}0.431^{* *} \\
(2.4000)\end{array}$ & $\begin{array}{c}0.155 \\
(0.7600)\end{array}$ & $\begin{array}{l}0.455^{* * *} \\
(2.5900)\end{array}$ \\
\hline GDP_Growth & $\begin{array}{l}0.0418^{* * *} \\
(4.0000)\end{array}$ & $\begin{array}{l}0.0488^{* * *} \\
(4.0800)\end{array}$ & $\begin{array}{l}0.0445^{* * *} \\
(4.3500)\end{array}$ & $\begin{array}{l}0.0313^{* * *} \\
(3.0300)\end{array}$ & $\begin{array}{l}0.0456^{* * *} \\
(3.8900)\end{array}$ & $\begin{array}{l}0.0334^{* * *} \\
(3.2900)\end{array}$ \\
\hline FI_Growth & $\begin{array}{c}-0.00778 \\
(-0.44)\end{array}$ & $\begin{array}{c}-0.000929 \\
(-0.04)\end{array}$ & $\begin{array}{c}-0.00822 \\
(-0.47)\end{array}$ & $\begin{array}{l}0.00149 \\
(0.0800)\end{array}$ & $\begin{array}{l}0.00187 \\
(0.0900)\end{array}$ & $\begin{array}{l}0.00149 \\
(0.0900)\end{array}$ \\
\hline _cons & $\begin{array}{c}3.060 * \\
(1.6900) \\
\end{array}$ & $\begin{array}{c}0.373 \\
(0.1800) \\
\end{array}$ & $\begin{array}{c}2.621 \\
(1.5000) \\
\end{array}$ & $\begin{array}{l}-2.860^{*} \\
(-1.80)\end{array}$ & $\begin{array}{l}-2.112 \\
(-1.19)\end{array}$ & $\begin{array}{c}-3.418^{* *} \\
(-2.24)\end{array}$ \\
\hline $\begin{array}{l}\mathrm{N} \\
\text { Country } \\
\text { effect }\end{array}$ & $\begin{array}{l}959 \\
\text { Yes }\end{array}$ & $\begin{array}{l}910 \\
\text { Yes }\end{array}$ & 946 & $\begin{array}{l}959 \\
\text { Yes }\end{array}$ & 910 & $\begin{array}{l}946 \\
\text { Yes }\end{array}$ \\
\hline
\end{tabular}

$\mathrm{t}$ statistic between parentheses. ${ }^{*}, * *$, and $* * *$ indicate statistical significance at $10 \%, 5 \%$, and $1 \%$, respectively. 
Z-score $=$ Natural logarithm of Z-score, a measure of stability. Z1= natural logarithm of Z1, a measure of bank asset risk. Z2= natural logarithm of Z2, a measure of leverage risk. FS: dummy variable that takes the value of one if the bank owns on foreign subsidiary or more, zero otherwise. ASdate, GFC, Islamic, and Window are dummy variables that take the value of one if the date is 2011 or 2012, 2008 or 2009, if the bank is considered Islamic, and if the bank is conventional with an Islamic window, respectively, or zero otherwise. GOBs: percentage of bank ownership held by governmental institutes. OC: percentage of the highest shareholder shares. CAR: the ratio of equity to total assets. NPL: ratio of impaired loans to total loans. Size: natural logarithm of assets. Divers $=1-\mid$ (net interest revenue - other operating income) / operating income|. HHI= Herfindhal-Hirschman index, a measure of market concentration. GGL: growth of gross loans. GDP: natural logarithm of GDP per capita. GDP_Growth: annual growth rate of GDP per capita. FI_growth: annual growth rate of foreign investments. 
Table 7 MENA banks stability and the effects of the 'Arab Spring' and the Global Financial Crisis (Hausman Taylor model). Effects of subsidiaries during crises

\begin{tabular}{|c|c|c|c|c|c|c|}
\hline & $\begin{array}{c}\text { Z-score } \\
1\end{array}$ & $\begin{array}{c}\mathrm{Z1} \\
2\end{array}$ & $\begin{array}{c}Z 2 \\
3\end{array}$ & $\begin{array}{c}\text { Z-score } \\
4\end{array}$ & $\begin{array}{c}\mathrm{Z1} \\
5\end{array}$ & $\begin{array}{c}Z 2 \\
6\end{array}$ \\
\hline Asdate $(\beta 1)$ & $\begin{array}{c}0.266^{* *} \\
-2.4\end{array}$ & $\begin{array}{c}0.0105 \\
-0.08\end{array}$ & $\begin{array}{c}0.307^{* * *} \\
-2.84\end{array}$ & & & \\
\hline GFC ( $(\beta 1)$ & & & & $\begin{array}{c}-0.283^{* * *} \\
(-2.83)\end{array}$ & $\begin{array}{l}-0.209^{*} \\
(-1.85)\end{array}$ & $\begin{array}{c}-0.286^{* * *} \\
(-2.92)\end{array}$ \\
\hline $\mathrm{FS}(\beta 2)$ & $\begin{array}{l}-0.411^{* *} \\
(-2.38)\end{array}$ & $\begin{array}{l}-0.222 \\
(-1.10)\end{array}$ & $\begin{array}{c}-0.324^{* *} \\
(-2.01)\end{array}$ & $\begin{array}{c}-0.455^{* * *} \\
(-2.66)\end{array}$ & $\begin{array}{l}-0.192 \\
(-0.97)\end{array}$ & $\begin{array}{l}-0.348^{* *} \\
(-2.22)\end{array}$ \\
\hline FS_AS ( $\beta 3)$ & $\begin{array}{c}0.307^{* *} \\
-2.39\end{array}$ & $\begin{array}{l}0.225 \\
-1.53\end{array}$ & $\begin{array}{c}0.252^{* *} \\
-2.01\end{array}$ & & & \\
\hline FS_GFC ( $\beta 3)$ & & & & $\begin{array}{c}-0.0681 \\
(-0.53)\end{array}$ & $\begin{array}{c}0.0171 \\
-0.12\end{array}$ & $\begin{array}{c}-0.0731 \\
(-0.58)\end{array}$ \\
\hline GOBs & $\begin{array}{c}0.00183 \\
-0.62\end{array}$ & $\begin{array}{c}-0.00388 \\
(-1.10)\end{array}$ & $\begin{array}{c}0.00104 \\
-0.38\end{array}$ & $\begin{array}{c}0.000931 \\
-0.32\end{array}$ & $\begin{array}{c}-0.00392 \\
(-1.14)\end{array}$ & $\begin{array}{c}0.000201 \\
-0.08\end{array}$ \\
\hline Islamic & $\begin{array}{l}-0.263 \\
(-1.24)\end{array}$ & $\begin{array}{c}-0.750^{* * *} \\
(-2.93)\end{array}$ & $\begin{array}{l}-0.256 \\
(-1.30)\end{array}$ & $\begin{array}{l}-0.215 \\
(-1.04)\end{array}$ & $\begin{array}{c}-0.735^{* * *} \\
(-2.99)\end{array}$ & $\begin{array}{c}-0.21 \\
(-1.13)\end{array}$ \\
\hline Window & $\begin{array}{r}0.027 \\
-0.12\end{array}$ & $\begin{array}{l}-0.069 \\
(-0.25)\end{array}$ & $\begin{array}{c}-0.0575 \\
(-0.28)\end{array}$ & $\begin{array}{l}-0.102 \\
(-0.46)\end{array}$ & $\begin{array}{c}-0.0955 \\
(-0.36)\end{array}$ & $\begin{array}{l}-0.176 \\
(-0.89)\end{array}$ \\
\hline OC & $\begin{array}{c}-0.00634^{* *} \\
(-2.27)\end{array}$ & $\begin{array}{c}-0.00095 \\
(-0.28)\end{array}$ & $\begin{array}{c}-0.00525^{* *} \\
(-2.00)\end{array}$ & $\begin{array}{c}-0.00525^{*} \\
(-1.92)\end{array}$ & $\begin{array}{c}-0.00068 \\
(-0.21)\end{array}$ & $\begin{array}{c}-0.00427^{*} \\
(-1.71)\end{array}$ \\
\hline CAR & $\begin{array}{l}0.325 \\
-0.29\end{array}$ & $\begin{array}{l}1.988 \\
-1.35\end{array}$ & $\begin{array}{l}1.742 \\
-1.36\end{array}$ & $\begin{array}{l}0.506 \\
-0.44\end{array}$ & $\begin{array}{l}2.152 \\
-1.46\end{array}$ & $\begin{array}{l}1.983 \\
-1.55\end{array}$ \\
\hline NPL & $\begin{array}{c}-0.00865 \\
(-1.59)\end{array}$ & $\begin{array}{c}-0.0142^{* *} \\
(-2.19)\end{array}$ & $\begin{array}{c}-0.00648 \\
(-1.22)\end{array}$ & $\begin{array}{c}-0.00721 \\
(-1.32)\end{array}$ & $\begin{array}{c}-0.0145^{* *} \\
(-2.22)\end{array}$ & $\begin{array}{c}-0.00413 \\
(-0.77)\end{array}$ \\
\hline SIZE & $\begin{array}{c}0.07 \\
-0.73\end{array}$ & $\begin{array}{c}0.162 \\
-1.5\end{array}$ & $\begin{array}{c}0.0844 \\
-0.92\end{array}$ & $\begin{array}{c}0.206^{* *} \\
-2.05\end{array}$ & $\begin{array}{c}0.195^{*} \\
-1.73\end{array}$ & $\begin{array}{c}0.200^{* *} \\
-2.11\end{array}$ \\
\hline Divers & $\begin{array}{l}-0.315 \\
(-1.63)\end{array}$ & $\begin{array}{l}-0.257 \\
(-1.13)\end{array}$ & $\begin{array}{l}-0.365^{*} \\
(-1.93)\end{array}$ & $\begin{array}{c}-0.457^{* *} \\
(-2.36)\end{array}$ & $\begin{array}{l}-0.308 \\
(-1.36)\end{array}$ & $\begin{array}{c}-0.517^{* * *} \\
(-2.73)\end{array}$ \\
\hline $\mathrm{HHI}$ & $\begin{array}{l}1.511 \\
-0.79\end{array}$ & $\begin{array}{l}1.448 \\
-0.66\end{array}$ & $\begin{array}{l}1.626 \\
-0.87\end{array}$ & $\begin{array}{l}2.449 \\
-1.26\end{array}$ & $\begin{array}{l}1.893 \\
-0.87\end{array}$ & $\begin{array}{l}2.697 \\
-1.42\end{array}$ \\
\hline GGL & $\begin{array}{c}-0.00447^{* * *} \\
(-3.23)\end{array}$ & $\begin{array}{c}-0.00395^{* *} \\
(-2.42)\end{array}$ & $\begin{array}{c}-0.00444^{* * *} \\
(-3.18)\end{array}$ & $\begin{array}{c}-0.00510^{* * *} \\
(-3.66)\end{array}$ & $\begin{array}{c}-0.00420^{* * *} \\
(-2.59)\end{array}$ & $\begin{array}{c}-0.00499^{* * *} \\
(-3.54)\end{array}$ \\
\hline GDP & $\begin{array}{c}-0.0203 \\
(-0.11)\end{array}$ & $\begin{array}{c}-0.0496 \\
(-0.23)\end{array}$ & $\begin{array}{c}-0.0414 \\
(-0.22)\end{array}$ & $\begin{array}{c}0.429^{* *} \\
-2.39\end{array}$ & $\begin{array}{c}0.152 \\
-0.75\end{array}$ & $\begin{array}{c}0.453^{* * *} \\
-2.58\end{array}$ \\
\hline GDP_Growth & $\begin{array}{c}0.0420^{* * *} \\
-4.06\end{array}$ & $\begin{array}{c}0.0498^{* * *} \\
-4.21\end{array}$ & $\begin{array}{c}0.0451^{* * *} \\
-4.45\end{array}$ & $\begin{array}{c}0.0313^{* * *} \\
-3.03\end{array}$ & $\begin{array}{c}0.0456^{* * *} \\
-3.89\end{array}$ & $\begin{array}{c}0.0334^{* * *} \\
-3.3\end{array}$ \\
\hline FI_Growth & $\begin{array}{c}-0.00902 \\
(-0.51)\end{array}$ & $\begin{array}{c}-0.0012 \\
(-0.06)\end{array}$ & $\begin{array}{c}-0.00928 \\
(-0.54)\end{array}$ & $\begin{array}{c}0.000795 \\
-0.04\end{array}$ & $\begin{array}{c}0.00177 \\
-0.09\end{array}$ & $\begin{array}{c}0.000722 \\
-0.04\end{array}$ \\
\hline _cons & $\begin{array}{c}3.042^{*} \\
-1.7\end{array}$ & $\begin{array}{c}0.221 \\
-0.11\end{array}$ & $\begin{array}{r}2.556 \\
-1.48\end{array}$ & $\begin{array}{l}-2.860^{*} \\
(-1.80)\end{array}$ & $\begin{array}{l}-2.026 \\
(-1.15)\end{array}$ & $\begin{array}{l}-3.422^{* *} \\
(-2.24)\end{array}$ \\
\hline $\begin{array}{l}\mathrm{N} \\
\text { Country } \\
\text { effect } \\
\text { Wald: }\end{array}$ & $\begin{array}{l}959 \\
\text { Yes }\end{array}$ & $\begin{array}{l}910 \\
\text { Yes }\end{array}$ & $\begin{array}{l}946 \\
\text { Yes }\end{array}$ & $\begin{array}{l}959 \\
\text { Yes }\end{array}$ & 910 & 946 \\
\hline
\end{tabular}




$\begin{array}{cc}- & -0.072 \\ - & 0.559 * * *\end{array}$

$\mathrm{t}$ statistics between parentheses. $*, * *$, and $* * *$ indicate statistical significance at 10\%, 5\%, and $1 \%$, respectively.

Z-score $=$ Natural logarithm of Z-score, a measure of stability. Z1= natural logarithm of Z1, a measure of bank asset risk. Z2= natural logarithm of Z2, a measure of leverage risk. FS: dummy variable that takes the value of one if the bank owns on foreign subsidiary or more, zero otherwise. ASdate, GFC, Islamic, and Window are dummy variables that take the value of one if the date is 2011 or 2012, 2008 or 2009 , if the bank is considered Islamic, and if the bank is conventional with an Islamic window, respectively, or zero otherwise. FS_AS: interaction between ASdate and FS. FS_GFC: interaction between FS and GFC. GOBs: percentage of bank ownership held by governmental institutes. OC: percentage of the highest shareholder shares. CAR: the ratio of equity to total assets. NPL: ratio of impaired loans to total loans. Size: natural logarithm of assets. Divers $=1-\mid$ (net interest revenue - other operating income) $/$ operating income $\mid$. HHI= Herfindhal-Hirschman index, a measure of market concentration. GGL: growth of gross loans. GDP: natural logarithm of GDP per capita. GDP_Growth: annual growth rate of GDP per capita. FI_growth: annual growth rate of foreign investments. 
Table 8 MENA banks stability and the effects of the 'Arab Spring' (Hausman Taylor model). Grouped subsidiaries by region. Dependent variable is Z-Score.

\begin{tabular}{|c|c|c|c|c|c|c|}
\hline & $(1)$ & $(2)$ & (3) & (4) & $(5)$ & (6) \\
\hline \multirow[t]{2}{*}{ ASdate $(\beta 1)$} & $0.447^{* * *}$ & $0.387^{* * *}$ & $0.449^{* * *}$ & $0.358^{* * *}$ & $0.281^{* * *}$ & $0.434^{* * *}$ \\
\hline & $(5.12)$ & $(4.32)$ & $(5.22)$ & (3.77) & $(2.74)$ & $(4.95)$ \\
\hline \multirow[t]{2}{*}{ FS_Africa } & 0.205 & & & & & \\
\hline & $(0.55)$ & & & & & \\
\hline \multirow[t]{2}{*}{ FS_Africa_AS } & 0.052 & & & & & \\
\hline & $(0.16)$ & & & & & \\
\hline \multirow[t]{2}{*}{ FS_S.America ( $\beta 2)$} & & $-0.719^{* * *}$ & & & & \\
\hline & & $(-2.66)$ & & & & \\
\hline \multirow{2}{*}{$\begin{array}{l}\text { FS_S.America_AS } \\
(\beta 3)\end{array}$} & & $0.466^{* *}$ & & & & \\
\hline & & $(2.06)$ & & & & \\
\hline \multirow[t]{2}{*}{ FS_Asia ( $\beta 2)$} & & & 0.00765 & & & \\
\hline & & & $(0.03)$ & & & \\
\hline \multirow[t]{2}{*}{ FS_Asia_AS ( $\beta 3)$} & & & 0.170 & & & \\
\hline & & & $(0.80)$ & & & \\
\hline \multirow[t]{2}{*}{ FS_Europe $(\beta 2)$} & & & & -0.036 & & \\
\hline & & & & $(-0.15)$ & & \\
\hline \multirow[t]{2}{*}{ FS_Europe_AS ( $\beta 3)$} & & & & $0.371^{* *}$ & & \\
\hline & & & & $(2.42)$ & & \\
\hline \multirow[t]{2}{*}{ FS_MENA ( $\beta 2)$} & & & & & -0.265 & \\
\hline & & & & & $(-1.26)$ & \\
\hline \multirow[t]{2}{*}{ FS_MENA_AS ( $\beta 3)$} & & & & & $0.406^{* * *}$ & \\
\hline & & & & & $(2.94)$ & \\
\hline \multirow[t]{2}{*}{ FS_USA ( $\beta 2)$} & & & & & & -0.0157 \\
\hline & & & & & & $(-0.04)$ \\
\hline \multirow[t]{2}{*}{ FS_USA_AS ( $\beta 3)$} & & & & & & 0.295 \\
\hline & & & & & & $(0.93)$ \\
\hline \multirow[t]{2}{*}{ GOBs } & 0.000936 & 0.00216 & 0.000737 & 0.00111 & 0.00127 & 0.000964 \\
\hline & $(0.27)$ & $(0.64)$ & $(0.21)$ & $(0.33)$ & $(0.38)$ & $(0.29)$ \\
\hline \multirow[t]{2}{*}{ Islamic } & $-0.389^{*}$ & -0.265 & $-0.390^{*}$ & $-0.386^{*}$ & -0.356 & $-0.390^{*}$ \\
\hline & $(-1.72)$ & $(-1.14)$ & $(-1.68)$ & $(-1.68)$ & $(-1.57)$ & $(-1.68)$ \\
\hline \multirow[t]{2}{*}{ Window } & 0.00754 & 0.0819 & 0.00324 & 0.0161 & 0.0385 & 0.00816 \\
\hline & $(0.03)$ & $(0.34)$ & $(0.01)$ & $(0.07)$ & $(0.16)$ & $(0.03)$ \\
\hline \multirow[t]{2}{*}{$\mathrm{OC}$} & -0.0041 & -0.00378 & -0.00421 & -0.00408 & -0.00474 & -0.00418 \\
\hline & $(-1.35)$ & $(-1.23)$ & $(-1.37)$ & $(-1.37)$ & $(-1.58)$ & $(-1.36)$ \\
\hline \multirow[t]{2}{*}{ CAR } & 0.529 & 0.772 & 0.453 & 0.467 & 0.458 & 0.421 \\
\hline & $(0.44)$ & $(0.66)$ & $(0.37)$ & $(0.40)$ & (0.39) & $(0.35)$ \\
\hline \multirow[t]{2}{*}{ NPL } & -0.00851 & -0.00841 & -0.00835 & $-0.00956^{*}$ & $-0.00965^{*}$ & -0.00825 \\
\hline & $(-1.52)$ & $(-1.51)$ & $(-1.50)$ & $(-1.74)$ & $(-1.74)$ & $(-1.48)$ \\
\hline \multirow[t]{2}{*}{ SIZE } & 0.0378 & 0.0678 & 0.035 & 0.0132 & 0.0471 & 0.0259 \\
\hline & $(0.36)$ & $(0.66)$ & $(0.32)$ & $(0.12)$ & $(0.42)$ & $(0.24)$ \\
\hline \multirow[t]{2}{*}{ Divers } & $-0.459^{* *}$ & $-0.437^{* *}$ & $-0.464^{* *}$ & $-0.511^{* *}$ & $-0.415^{* *}$ & $-0.468^{* *}$ \\
\hline & $(-2.18)$ & $(-2.09)$ & $(-2.20)$ & $(-2.43)$ & $(-1.97)$ & $(-2.22)$ \\
\hline $\mathrm{HHI}$ & 1.244 & 0.905 & 1.224 & 1.16 & 1.658 & 0.988 \\
\hline & $(0.61)$ & $(0.45)$ & $(0.60)$ & $(0.57)$ & $(0.82)$ & $(0.48)$ \\
\hline GGI & - & - & - & - & - & - \\
\hline U & $0.00409^{* * *}$ & $0.00393^{* * *}$ & $0.00407^{* * *}$ & $0.00410^{* * *}$ & $0.00420^{* * *}$ & $0.00403^{* * *}$ \\
\hline & $(-2.83)$ & $(-2.73)$ & $(-2.81)$ & $(-2.85)$ & $(-2.93)$ & $(-2.79)$ \\
\hline GDP & 0.0367 & 0.0394 & 0.0417 & 0.0326 & 0.00769 & 0.0551 \\
\hline & $(0.18)$ & (0.19) & $(0.20)$ & $(0.16)$ & $(0.04)$ & $(0.27)$ \\
\hline
\end{tabular}




\begin{tabular}{l|llllll} 
GDP_Growth & $0.0393^{* * *}$ & $0.0387^{* * *}$ & $0.0391^{* * *}$ & $0.0408^{* * *}$ & $0.0395^{* * *}$ & $0.0386^{* * *}$ \\
& $(3.52)$ & $(3.50)$ & $(3.51)$ & $(3.66)$ & $(3.56)$ & $(3.46)$ \\
FI_Growth & -0.019 & -0.021 & -0.019 & -0.0202 & -0.0211 & -0.0192 \\
& $(-1.00)$ & $(-1.12)$ & $(-1.00)$ & $(-1.07)$ & $(-1.12)$ & $(-1.01)$ \\
_cons & 3.102 & 2.431 & 3.129 & $3.613^{*}$ & 3.205 & 3.193 \\
& $(1.59)$ & $(1.25)$ & $(1.59)$ & $(1.83)$ & $(1.64)$ & $(1.63)$ \\
\hline $\mathrm{N}$ & 858 & 858 & 858 & 858 & 858 & 858 \\
\hline Country effect & Yes & Yes & Yes & Yes & Yes & Yes \\
Wald: & & & & & & \\
$(\beta 2)+(\beta 3)$ & - & -0.253 & - & 1.65 & 0.141 & - \\
$(\beta 1)+(\beta 3)$ & - & $0.853^{* * *}$ & - & $0.729 * * *$ & $0.687^{* * *}$ & - \\
\hline
\end{tabular}

t statistic is between parentheses. ${ }^{*},{ }^{* *}$, and ${ }^{* * *}$ indicate statistical significance at $10 \%, 5 \%$, and $1 \%$, respectively.

Z-score= Natural logarithm of Z-score, a measure of stability. FS_Africa, FS_S.America, FS_Asia, FS_Europe, FS_MENA, FS_USA: dummy variables that take the value of one if the bank owns one foreign subsidiary or more in the said region, zero otherwise. FS_Africa_AS, FS_S.America_AS, FS_Asia_AS, FS_Europe_AS, FS_MENA_AS, FS_USA_AS: interaction variable between the region variable and the Arab Spring variable. ASdate, Islamic, and Window are dummy variables that take the value of one if the date is 2011 or 2012, if the bank is considered Islamic, and if the bank is conventional with an Islamic window, respectively, or zero otherwise. GOBs: percentage of bank ownership held by governmental institutes. OC: percentage of the highest shareholder shares. CAR: the ratio of equity to total assets. NPL: ratio of impaired loans to total loans. Size: natural logarithm of assets. Divers $=1-\mid$ (net interest revenue - other operating income) / operating income $\mid$. $\mathrm{HHI}=$ Herfindhal-Hirschman index, a measure of market concentration. GGL: growth of gross loans. GDP: natural logarithm of GDP per capita. GDP_Growth: annual growth rate of GDP per capita. FI_growth: annual growth rate of foreign investments. 
Table 9 MENA banks stability and the effects of the 'Global Financial Crisis' (Hausman Taylor model). Grouped subsidiaries by region. Dependent variable is Z-Score.

\begin{tabular}{|c|c|c|c|c|c|c|}
\hline & (1) & (2) & (3) & (4) & (5) & (6) \\
\hline \multirow[t]{2}{*}{ GFC ( $\beta 1)$} & $-0.321^{* * *}$ & $-0.312^{* * *}$ & $-0.336^{* * *}$ & $-0.263^{* * *}$ & $-0.271^{* * *}$ & $-0.336^{* * *}$ \\
\hline & $(-4.54)$ & $(-4.31)$ & $(-4.89)$ & $(-3.25)$ & $(-2.97)$ & $(-4.78)$ \\
\hline \multirow[t]{2}{*}{ FS_Africa } & 0.122 & & & & & \\
\hline & $(0.33)$ & & & & & \\
\hline \multirow[t]{2}{*}{ FS_Africa_GFC } & -0.279 & & & & & \\
\hline & $(-0.92)$ & & & & & \\
\hline \multirow[t]{2}{*}{ FS_S.America ( $\beta 2)$} & & $-0.705^{* * *}$ & & & & \\
\hline & & $(-2.70)$ & & & & \\
\hline \multirow{2}{*}{$\begin{array}{l}\text { FS_S.America_GFC } \\
\text { ( } \beta 3)\end{array}$} & & -0.228 & & & & \\
\hline & & $(-1.02)$ & & & & \\
\hline \multirow[t]{2}{*}{ FS_Asia } & & & -0.00799 & & & \\
\hline & & & $(-0.03)$ & & & \\
\hline FS_Asia_GFC & & & -0.0714 & & & \\
\hline- & & & $(-0.32)$ & & & \\
\hline \multirow[t]{2}{*}{ FS_Europe ( $\beta 2)$} & & & & -0.111 & & \\
\hline & & & & $(-0.48)$ & & \\
\hline \multirow[t]{2}{*}{ FS_Europe_GFC ( $\beta 3)$} & & & & $-0.252^{*}$ & & \\
\hline & & & & $(-1.69)$ & & \\
\hline \multirow[t]{2}{*}{ FS_MENA ( $\beta 2)$} & & & & & -0.312 & \\
\hline & & & & & $(-1.50)$ & \\
\hline \multirow[t]{2}{*}{ FS_MENA_GFC ( $\beta 3)$} & & & & & -0.154 & \\
\hline & & & & & $(-1.12)$ & \\
\hline \multirow[t]{2}{*}{ FS_USA ( $\beta 2)$} & & & & & & -0.194 \\
\hline & & & & & & $(-0.47)$ \\
\hline \multirow[t]{2}{*}{ FS_USA_GFC ( $\beta 3)$} & & & & & & -0.0224 \\
\hline & & & & & & $(-0.07)$ \\
\hline \multirow[t]{2}{*}{ GOBs } & -0.000823 & 0.00079 & -0.000706 & 0.000564 & -0.00049 & -0.00043 \\
\hline & $(-0.24)$ & $(0.24)$ & $(-0.21)$ & $(0.17)$ & $(-0.15)$ & $(-0.13)$ \\
\hline \multirow[t]{2}{*}{ Islamic } & $-0.375^{*}$ & -0.195 & -0.366 & -0.319 & -0.33 & -0.342 \\
\hline & $(-1.68)$ & $(-0.88)$ & $(-1.60)$ & $(-1.40)$ & $(-1.49)$ & $(-1.49)$ \\
\hline \multirow[t]{2}{*}{ Window } & -0.133 & -0.0421 & -0.13 & -0.0893 & -0.103 & -0.112 \\
\hline & $(-0.55)$ & $(-0.18)$ & $(-0.54)$ & $(-0.38)$ & $(-0.43)$ & $(-0.47)$ \\
\hline \multirow[t]{2}{*}{ OC } & -0.00283 & -0.0023 & -0.0029 & -0.0037 & -0.00384 & -0.00329 \\
\hline & $(-0.95)$ & $(-0.78)$ & $(-0.96)$ & $(-1.26)$ & $(-1.31)$ & $(-1.09)$ \\
\hline \multirow[t]{2}{*}{ CAR } & 0.854 & 0.733 & 0.777 & 0.618 & 0.788 & 0.744 \\
\hline & $(0.72)$ & $(0.63)$ & $(0.65)$ & $(0.52)$ & $(0.66)$ & $(0.62)$ \\
\hline \multirow[t]{2}{*}{ NPL } & -0.00833 & -0.00756 & -0.00815 & -0.00892 & -0.00901 & -0.0082 \\
\hline & $(-1.51)$ & $(-1.36)$ & $(-1.47)$ & $(-1.62)$ & $(-1.63)$ & $(-1.48)$ \\
\hline \multirow[t]{2}{*}{ SIZE } & $0.177^{*}$ & $0.211^{* *}$ & $0.179^{*}$ & 0.156 & $0.212^{*}$ & $0.175^{*}$ \\
\hline & $(1.70)$ & $(2.04)$ & (1.69) & $(1.41)$ & $(1.87)$ & $(1.67)$ \\
\hline \multirow[t]{2}{*}{ Divers } & $-0.622^{* * *}$ & $-0.588^{* * *}$ & $-0.611^{* * *}$ & $-0.618^{* * *}$ & $-0.561^{* * *}$ & $-0.608^{* * *}$ \\
\hline & $(-2.95)$ & $(-2.80)$ & $(-2.89)$ & $(-2.94)$ & $(-2.65)$ & $(-2.88)$ \\
\hline \multirow[t]{2}{*}{$\mathrm{HHI}$} & 2.156 & 1.828 & 2.215 & 2.13 & 2.011 & 2.205 \\
\hline & (1.05) & (0.89) & (1.08) & (1.04) & (0.97) & (1.07) \\
\hline \multirow{3}{*}{ GGL } & - & - & - & - & - & - \\
\hline & $0.00472^{* * *}$ & $0.00464^{* * *}$ & $0.00473^{* * *}$ & $0.00487^{* * *}$ & $0.00502^{* * *}$ & $0.00477^{* * *}$ \\
\hline & $(-3.24)$ & $(-3.20)$ & $(-3.25)$ & $(-3.36)$ & $(-3.47)$ & $(-3.28)$ \\
\hline
\end{tabular}




\begin{tabular}{l|llllll} 
GDP & $0.468^{* *}$ & $0.435^{* *}$ & $0.468^{* *}$ & $0.497^{* * *}$ & $0.429^{* *}$ & $0.476^{* *}$ \\
\multirow{3}{*}{ GDP_Growth } & $(2.52)$ & $(2.34)$ & $(2.49)$ & $(2.61)$ & $(2.23)$ & $(2.55)$ \\
& $0.0305^{* * *}$ & $0.0298^{* * *}$ & $0.0296^{* * *}$ & $0.0309^{* * *}$ & $0.0306^{* * *}$ & $0.0295^{* * *}$ \\
FI_Growth & $(2.74)$ & $(2.68)$ & $(2.68)$ & $(2.76)$ & $(2.75)$ & $(2.64)$ \\
& -0.012 & -0.0121 & -0.011 & -0.012 & -0.011 & -0.011 \\
\multirow{2}{*}{ cons } & $(-0.63)$ & $(-0.64)$ & $(-0.58)$ & $(-0.63)$ & $(-0.58)$ & $(-0.58)$ \\
& -2.646 & $-3.145^{*}$ & -2.679 & -2.55 & -2.846 & -2.694 \\
\hline N & $(-1.54)$ & $(-1.82)$ & $(-1.55)$ & $(-1.46)$ & $(-1.63)$ & $(-1.55)$ \\
\hline Country effect & 858 & 858 & 858 & 858 & 858 & 858 \\
Wald: & Yes & Yes & Yes & Yes & Yes & Yes \\
$(\beta 2)+(\beta 3)$ & - & - & - & -0.363 & - & - \\
$(\beta 1)+(\beta 3)$ & - & - & - & $-0.515^{* * *}$ & - & - \\
\hline
\end{tabular}

t statistic is between parentheses. ${ }^{*},{ }^{* *}$, and ${ }^{* * *}$ indicate statistical significance at $10 \%, 5 \%$, and $1 \%$, respectively.

Z-score $=$ Natural logarithm of Z-score, a measure of stability. FS_Africa, FS_S.America, FS_Asia, FS_Europe, FS_MENA, FS_USA: dummy variables that take the value of one if the bank owns one foreign subsidiary or more in the said region, zero otherwise. FS_Africa_GFC, FS_S.America_GFC, FS_Asia_GFC, FS_Europe_GFC, FS_MENA_GFC, FS_USA_GFC: interaction variable between the region variable and the GFC variable. GFC, Islamic, and Window are dummy variables that take the value of one if the date is 2008 or 2009, if the bank is considered Islamic, and if the bank is conventional with an Islamic window, respectively, or zero otherwise. GOBs: percentage of bank ownership held by governmental institutes. OC: percentage of the highest shareholder shares. CAR: the ratio of equity to total assets. NPL: ratio of impaired loans to total loans. Size: natural logarithm of assets. Divers=1- | (net interest revenue - other operating income) / operating incomel. $\mathrm{HHI}=$ Herfindhal-Hirschman index, a measure of market concentration. GGL: growth of gross loans. GDP: natural logarithm of GDP per capita. GDP_Growth: annual growth rate of GDP per capita. FI_growth: annual growth rate of foreign investments. 
Table 10 MENA banks stability and the effects of the 'Arab Springs'and the 'Global Financial Crisis' (Hausman

Taylor model) for banks with subsidiaries in one region, two regions, and three or more regions. Dependent variable is Z-Score.

\begin{tabular}{|c|c|c|c|c|c|c|}
\hline & (1) & (2) & (3) & (4) & (5) & (6) \\
\hline Asdate $(\beta 1)$ & $\begin{array}{c}0.431^{* * *} \\
(4.48)\end{array}$ & $\begin{array}{c}0.426^{* * *} \\
(4.75)\end{array}$ & $\begin{array}{c}0.382^{* * *} \\
(4.25)\end{array}$ & & & \\
\hline GFC ( $\beta 1)$ & & & & $\begin{array}{c}-0.400^{* * *} \\
(-5.03)\end{array}$ & $\begin{array}{c}-0.302^{* * *} \\
(-4.06)\end{array}$ & $\begin{array}{c}-0.289^{* * * *} \\
(-3.92)\end{array}$ \\
\hline 1 Region ( $\beta 2$ ) & $\begin{array}{l}-0.231 \\
(-1.26)\end{array}$ & & & $\begin{array}{l}-0.295^{*} \\
(-1.65)\end{array}$ & & \\
\hline 1 Region AS ( $\beta 3$ ) & $\begin{array}{c}0.0596 \\
(0.39)\end{array}$ & & & & & \\
\hline 2 Regions ( $\beta 2$ ) & & $\begin{array}{l}-0.228 \\
(-0.98)\end{array}$ & & & $\begin{array}{l}-0.225 \\
(-0.99)\end{array}$ & \\
\hline 2 Regions AS ( $\beta 3$ ) & & $\begin{array}{l}0.174 \\
(0.90)\end{array}$ & & & & \\
\hline 3 Regions ( $\beta 2$ ) & & & $\begin{array}{l}-0.0706 \\
(-0.27)\end{array}$ & & & $\begin{array}{l}-0.115 \\
(-0.45)\end{array}$ \\
\hline 3 Regions AS ( $\beta 3$ ) & & & $\begin{array}{c}0.524^{* *} \\
(2.56)\end{array}$ & & & \\
\hline 1 region GFC $(\beta 3)$ & & & & $\begin{array}{l}0.246 \\
(1.58)\end{array}$ & & \\
\hline 2 regions GFC ( $\beta 3$ ) & & & & & $\begin{array}{l}-0.227 \\
(-1.21)\end{array}$ & \\
\hline 3 regions GFC ( $\beta 3$ ) & & & & & & $\begin{array}{l}-0.343^{*} \\
(-1.75)\end{array}$ \\
\hline GOBs & $\begin{array}{c}- \\
0.0000854 \\
(-0.02)\end{array}$ & $\begin{array}{c}0.00103 \\
(0.31)\end{array}$ & $\begin{array}{c}0.000902 \\
(0.27)\end{array}$ & $\begin{array}{c}-0.00195 \\
(-0.58)\end{array}$ & $\begin{array}{c}-0.000184 \\
(-0.06)\end{array}$ & $\begin{array}{c}-0.000211 \\
(-0.06)\end{array}$ \\
\hline Islamic & $\begin{array}{l}-0.411^{*} \\
(-1.83)\end{array}$ & $\begin{array}{l}-0.374 \\
(-1.63)\end{array}$ & $\begin{array}{l}-0.371 \\
(-1.63)\end{array}$ & $\begin{array}{l}-0.397^{*} \\
(-1.81)\end{array}$ & $\begin{array}{l}-0.323 \\
(-1.44)\end{array}$ & $\begin{array}{l}-0.335 \\
(-1.49)\end{array}$ \\
\hline Window & $\begin{array}{c}-0.0487 \\
(-0.20)\end{array}$ & $\begin{array}{c}0.0293 \\
(0.12)\end{array}$ & $\begin{array}{c}0.000872 \\
0.00\end{array}$ & $\begin{array}{l}-0.188 \\
(-0.78)\end{array}$ & $\begin{array}{c}-0.0822 \\
(-0.35)\end{array}$ & $\begin{array}{l}-0.116 \\
(-0.48)\end{array}$ \\
\hline OC & $\begin{array}{c}-0.00404 \\
(-1.33)\end{array}$ & $\begin{array}{c}-0.00402 \\
(-1.33)\end{array}$ & $\begin{array}{c}-0.00429 \\
(-1.42)\end{array}$ & $\begin{array}{c}-0.00281 \\
(-0.94)\end{array}$ & $\begin{array}{c}-0.0033 \\
(-1.11)\end{array}$ & $\begin{array}{c}-0.00302 \\
(-1.02)\end{array}$ \\
\hline CAR & $\begin{array}{c}0.47 \\
(0.39)\end{array}$ & $\begin{array}{c}0.78 \\
(0.66)\end{array}$ & $\begin{array}{l}0.265 \\
(0.22)\end{array}$ & $\begin{array}{l}0.791 \\
(0.66)\end{array}$ & $\begin{array}{l}0.747 \\
(0.63)\end{array}$ & $\begin{array}{c}0.88 \\
(0.74)\end{array}$ \\
\hline NPL & $\begin{array}{c}-0.00802 \\
(-1.44)\end{array}$ & $\begin{array}{c}-0.00872 \\
(-1.56)\end{array}$ & $\begin{array}{c}-0.00871 \\
(-1.57)\end{array}$ & $\begin{array}{c}-0.00828 \\
(-1.49)\end{array}$ & $\begin{array}{c}-0.00859 \\
(-1.56)\end{array}$ & $\begin{array}{c}-0.00877 \\
(-1.59)\end{array}$ \\
\hline SIZE & $\begin{array}{l}0.058 \\
(0.55)\end{array}$ & $\begin{array}{l}0.061 \\
(0.59)\end{array}$ & $\begin{array}{c}0.0292 \\
(0.27)\end{array}$ & $\begin{array}{l}0.191^{*} \\
(1.85)\end{array}$ & $\begin{array}{l}0.177^{*} \\
(1.71)\end{array}$ & $\begin{array}{l}0.191^{*} \\
(1.74)\end{array}$ \\
\hline Divers & $\begin{array}{c}-0.443^{* *} \\
(-2.11)\end{array}$ & $\begin{array}{c}-0.455^{* *} \\
(-2.16)\end{array}$ & $\begin{array}{l}-0.500^{* *} \\
(-2.38)\end{array}$ & $\begin{array}{c}-0.610^{* * *} \\
(-2.90)\end{array}$ & $\begin{array}{c}-0.618^{* * *} \\
(-2.94)\end{array}$ & $\begin{array}{c}-0.612^{* * *} \\
(-2.91)\end{array}$ \\
\hline $\mathrm{HHI}$ & $\begin{array}{l}1.322 \\
(0.65)\end{array}$ & $\begin{array}{l}1.203 \\
(0.59)\end{array}$ & $\begin{array}{c}1.35 \\
(0.66)\end{array}$ & $\begin{array}{l}2.166 \\
(1.05)\end{array}$ & $\begin{array}{l}2.187 \\
(1.06)\end{array}$ & $\begin{array}{l}1.968 \\
(0.96)\end{array}$ \\
\hline GGL & $\begin{array}{c}0.00404^{* * *} \\
(-2.79)\end{array}$ & $\begin{array}{c}0.00403^{* * *} \\
(-2.79)\end{array}$ & $\begin{array}{c}0.00397^{* * *} \\
(-2.75)\end{array}$ & $\begin{array}{c}0.00473^{* * *} \\
(-3.26)\end{array}$ & $\begin{array}{c}0.00477^{* * *} \\
(-3.29)\end{array}$ & $\begin{array}{c}- \\
0.00479^{* * *} \\
(-3.31)\end{array}$ \\
\hline GDP & 0.0194 & 0.000558 & 0.0504 & $0.458^{* *}$ & $0.474^{* *}$ & $0.452^{* *}$ \\
\hline
\end{tabular}




\begin{tabular}{l|cccccc} 
& $(0.09)$ & 0.00 & $(0.25)$ & $(2.46)$ & $(2.54)$ & $(2.39)$ \\
GDP_Growth & $0.0393^{* * *}$ & $0.0402^{* * *}$ & $0.0393^{* * *}$ & $0.0306^{* * *}$ & $0.0301^{* * *}$ & $0.0304^{* * *}$ \\
& $(3.52)$ & $(3.61)$ & $(3.52)$ & $(2.76)$ & $(2.72)$ & $(2.73)$ \\
FI_Growth & -0.0186 & -0.0201 & -0.0188 & -0.00903 & -0.0102 & -0.0128 \\
& $(-0.98)$ & $(-1.06)$ & $(-1.00)$ & $(-0.47)$ & $(-0.54)$ & $(-0.67)$ \\
\multirow{4}{*}{ cons } & 2.956 & 3.042 & 3.17 & -2.705 & -2.665 & -2.767 \\
& $(1.52)$ & $(1.57)$ & $(1.61)$ & $(-1.58)$ & $(-1.56)$ & $(-1.58)$ \\
\hline $\mathrm{N}$ & 858 & 858 & 858 & 858 & 858 & 858 \\
\hline Country effect & Yes & Yes & Yes & Yes & Yes & Yes \\
Wald: & & & & & & \\
$(\beta 2)+(\beta 3)$ & - & - & 0.45 & - & - & -0.458 \\
$(\beta 1)+(\beta 3)$ & - & - & $0.91^{* * *}$ & - & - & $-0.632 * * *$ \\
\hline
\end{tabular}

t statistic is between parentheses. ${ }^{*},{ }^{* *}$, and ${ }^{* * *}$ indicate statistical significance at $10 \%, 5 \%$, and $1 \%$, respectively.

Z-score $=$ Natural logarithm of Z-score, a measure of stability. 1_region: dummy variables that take the value of one if the bank owns a foreign subsidiary in one region, zero otherwise. 2_regions: dummy variables that take the value of one if the bank owns a foreign subsidiary in two regions, zero otherwise. 3_regions: dummy variables that take the value of one if the bank owns a foreign subsidiary in three or more regiona, zero otherwise. FS_Africa_AS, FS_S.America_AS, FS_Asia_AS, FS_Europe_AS, FS_MENA_AS, FS_USA_AS: interaction variable between the region variable and the Arab Spring variable. ASdate, GFC, Islamic, and Window are dummy variables that take the value of one if the date is 2011 or 2012, 2008 or 2009, if the bank is considered Islamic, and if the bank is conventional with an Islamic window, respectively, or zero otherwise. GOBs: percentage of bank ownership held by governmental institutes. OC: percentage of the highest shareholder shares. CAR: the ratio of equity to total assets. NPL: ratio of impaired loans to total loans. Size: natural logarithm of assets. Divers=1- I (net interest revenue - other operating income) / operating incomel. $\mathrm{HHI}=$ Herfindhal-Hirschman index, a measure of market concentration. GGL: growth of gross loans. GDP: natural logarithm of GDP per capita. GDP_Growth: annual growth rate of GDP per capita. FI_growth: annual growth rate of foreign investments. 
Table 11: MENA banks stability and the effects of the 'Arab Spring' (Random Effects model).

\begin{tabular}{|c|c|c|c|c|c|c|}
\hline & $\begin{array}{c}\text { Z-score } \\
1 \\
\end{array}$ & $\begin{array}{c}\mathrm{Z1} \\
2 \\
\end{array}$ & $\begin{array}{c}Z 2 \\
3\end{array}$ & $\begin{array}{c}\text { Z-score } \\
4 \\
\end{array}$ & $\begin{array}{c}\mathrm{Z1} \\
5 \\
\end{array}$ & $\begin{array}{c}Z 2 \\
6 \\
\end{array}$ \\
\hline ASdate & $\begin{array}{c}0.310 * * * \\
(0.1110)\end{array}$ & $\begin{array}{c}0.0171 \\
(0.1280)\end{array}$ & $\begin{array}{c}0.335^{* * *} \\
(0.1080)\end{array}$ & & & \\
\hline GFC & & & & $\begin{array}{c}-0.293 * * * \\
(0.1010)\end{array}$ & $\begin{array}{l}-0.231 * * \\
(0.1150)\end{array}$ & $\begin{array}{c}-0.287 * * * \\
(0.0978)\end{array}$ \\
\hline FS & $\begin{array}{c}-0.473 * * * \\
(0.1380)\end{array}$ & $\begin{array}{c}-0.373 * * \\
(0.1490)\end{array}$ & $\begin{array}{c}-0.368 * * * \\
(0.1290)\end{array}$ & $\begin{array}{c}-0.413 * * * \\
(0.1370)\end{array}$ & $\begin{array}{l}-0.324 * * \\
(0.1460)\end{array}$ & $\begin{array}{c}-0.307^{* *} \\
(0.1260)\end{array}$ \\
\hline FS_AS & $\begin{array}{l}0.297^{* *} \\
(0.1290)\end{array}$ & $\begin{array}{c}0.2260 \\
(0.1490)\end{array}$ & $\begin{array}{l}0.247^{* *} \\
(0.1260)\end{array}$ & & & \\
\hline FS_GFC & & & & $\begin{array}{l}-0.0564 \\
(0.1290)\end{array}$ & $\begin{array}{c}0.0363 \\
(0.1480)\end{array}$ & $\begin{array}{l}-0.0729 \\
(0.1270)\end{array}$ \\
\hline GOBs & $\begin{array}{c}0.0027 \\
(0.0025)\end{array}$ & $\begin{array}{l}-0.0035 \\
(0.0027)\end{array}$ & $\begin{array}{c}0.0018 \\
(0.0023)\end{array}$ & $\begin{array}{c}0.0026 \\
(0.0025)\end{array}$ & $\begin{array}{l}-0.0036 \\
(0.0027)\end{array}$ & $\begin{array}{c}0.0016 \\
(0.0023)\end{array}$ \\
\hline Islamic & $\begin{array}{l}-0.302 * \\
(0.1820)\end{array}$ & $\begin{array}{c}-0.748 * * * \\
(0.1970)\end{array}$ & $\begin{array}{l}-0.296^{*} \\
(0.1690)\end{array}$ & $\begin{array}{l}-0.2710 \\
(0.1820)\end{array}$ & $\begin{array}{c}-0.746 * * * \\
(0.1960)\end{array}$ & $\begin{array}{l}-0.2720 \\
(0.1680)\end{array}$ \\
\hline Window & $\begin{array}{c}0.0544 \\
(0.1900)\end{array}$ & $\begin{array}{l}-0.1420 \\
(0.2070)\end{array}$ & $\begin{array}{l}-0.0192 \\
(0.1760)\end{array}$ & $\begin{array}{l}-0.0197 \\
(0.1900)\end{array}$ & $\begin{array}{l}-0.1700 \\
(0.2060)\end{array}$ & $\begin{array}{l}-0.0925 \\
(0.1750)\end{array}$ \\
\hline OC & $\begin{array}{c}-0.00567 * * \\
(0.0024)\end{array}$ & $\begin{array}{l}-0.0001 \\
(0.0026)\end{array}$ & $\begin{array}{c}-0.00453 * * \\
(0.0022)\end{array}$ & $\begin{array}{c}-0.00551 * * \\
(0.0024)\end{array}$ & $\begin{array}{c}0.0000 \\
(0.0026)\end{array}$ & $\begin{array}{c}-0.00428 * \\
(0.0022)\end{array}$ \\
\hline CAR & $\begin{array}{c}1.1740 \\
(0.7700)\end{array}$ & $\begin{array}{l}2.038 * * \\
(0.9800)\end{array}$ & $\begin{array}{c}2.896 * * * \\
(0.8420)\end{array}$ & $\begin{array}{c}1.0250 \\
(0.7750)\end{array}$ & $\begin{array}{l}1.947 * * \\
(0.9790)\end{array}$ & $\begin{array}{c}2.949 * * * \\
(0.8440)\end{array}$ \\
\hline NPL & $\begin{array}{c}-0.0147^{* * *} \\
(0.0036)\end{array}$ & $\begin{array}{c}-0.0263 * * * \\
(0.0049)\end{array}$ & $\begin{array}{c}-0.0111 * * * \\
(0.0036)\end{array}$ & $\begin{array}{c}-0.0132 * * * \\
(0.0036)\end{array}$ & $\begin{array}{c}-0.0262 * * * \\
(0.0049)\end{array}$ & $\begin{array}{c}-0.00963 * * * \\
(0.0036)\end{array}$ \\
\hline SIZE & $\begin{array}{c}0.101^{*} \\
(0.0602)\end{array}$ & $\begin{array}{c}0.275^{* * *} \\
(0.0664)\end{array}$ & $\begin{array}{l}0.114^{* *} \\
(0.0572)\end{array}$ & $\begin{array}{l}0.137 * * \\
(0.0601)\end{array}$ & $\begin{array}{c}0.285 * * * \\
(0.0657)\end{array}$ & $\begin{array}{c}0.149 * * * \\
(0.0568)\end{array}$ \\
\hline Divers & $\begin{array}{l}-0.328^{*} \\
(0.1880)\end{array}$ & $\begin{array}{l}-0.3370 \\
(0.2180)\end{array}$ & $\begin{array}{c}-0.369 * * \\
(0.1830)\end{array}$ & $\begin{array}{c}-0.467^{* *} \\
(0.1890)\end{array}$ & $\begin{array}{l}-0.390 * \\
(0.2160)\end{array}$ & $\begin{array}{c}-0.509 * * * \\
(0.1830)\end{array}$ \\
\hline $\mathrm{HHI}$ & $\begin{array}{c}1.2840 \\
(1.9470)\end{array}$ & $\begin{array}{c}1.6900 \\
(2.2380)\end{array}$ & $\begin{array}{c}1.5180 \\
(1.9010)\end{array}$ & $\begin{array}{c}2.1410 \\
(1.9610)\end{array}$ & $\begin{array}{c}2.0040 \\
(2.2290)\end{array}$ & $\begin{array}{c}2.4380 \\
(1.9120)\end{array}$ \\
\hline GGL & $\begin{array}{c}-0.00438 * * * \\
(0.0013)\end{array}$ & $\begin{array}{c}-0.00429 * * * \\
(0.0016)\end{array}$ & $\begin{array}{c}-0.00440 * * * \\
(0.0013)\end{array}$ & $\begin{array}{c}-0.00529 * * * \\
(0.0013)\end{array}$ & $\begin{array}{c}-0.00456 * * * \\
(0.0016)\end{array}$ & $\begin{array}{c}-0.00522 * * * \\
(0.0014)\end{array}$ \\
\hline GDP & $\begin{array}{l}-0.2040 \\
(0.1740)\end{array}$ & $\begin{array}{l}-0.2980 \\
(0.1970)\end{array}$ & $\begin{array}{l}-0.1880 \\
(0.1690)\end{array}$ & $\begin{array}{l}0.385^{* *} \\
(0.1530)\end{array}$ & $\begin{array}{l}-0.0915 \\
(0.1720)\end{array}$ & $\begin{array}{c}0.397 * * * \\
(0.1490)\end{array}$ \\
\hline GDP_Growth & $\begin{array}{c}0.0432 * * * \\
(0.0102)\end{array}$ & $\begin{array}{c}0.0538 * * * \\
(0.0118)\end{array}$ & $\begin{array}{c}0.0463 * * * \\
(0.0100)\end{array}$ & $\begin{array}{c}0.0285 * * * \\
(0.0101)\end{array}$ & $\begin{array}{c}0.0486 * * * \\
(0.0116)\end{array}$ & $\begin{array}{c}0.0317^{* * *} \\
(0.0099)\end{array}$ \\
\hline FI_Growth & $\begin{array}{l}-0.0123 \\
(0.0179)\end{array}$ & $\begin{array}{l}-0.0039 \\
(0.0211)\end{array}$ & $\begin{array}{l}-0.0119 \\
(0.0174)\end{array}$ & $\begin{array}{l}-0.0027 \\
(0.0180)\end{array}$ & $\begin{array}{l}-0.0018 \\
(0.0210)\end{array}$ & $\begin{array}{l}-0.0030 \\
(0.0175)\end{array}$ \\
\hline _cons & $\begin{array}{l}4.187^{* *} \\
(1.6260) \\
\end{array}$ & $\begin{array}{c}0.6980 \\
(1.8470) \\
\end{array}$ & $\begin{array}{l}3.317 * * \\
(1.5840) \\
\end{array}$ & $\begin{array}{l}-1.2350 \\
(1.4160) \\
\end{array}$ & $\begin{array}{l}-1.1130 \\
(1.5950) \\
\end{array}$ & $\begin{array}{l}-2.0730 \\
(1.3720) \\
\end{array}$ \\
\hline $\begin{array}{l}\mathrm{N} \\
\mathrm{R} 2 \\
\text { Country effect } \\
\text { control }\end{array}$ & $\begin{array}{l}961 \\
0.22\end{array}$ & $\begin{array}{c}911 \\
0.24\end{array}$ & $\begin{array}{l}948 \\
0.23\end{array}$ & $\begin{array}{l}961 \\
0.21\end{array}$ & $\begin{array}{l}911 \\
0.24\end{array}$ & $\begin{array}{l}948 \\
0.23\end{array}$ \\
\hline
\end{tabular}


Standard errors are between parentheses. $*, * *$, and $* * *$ indicate statistical significance at $10 \%, 5 \%$, and $1 \%$, respectively.

Z-score $=$ Natural logarithm of Z-score, a measure of stability. Z1= natural logarithm of Z1, a measure of bank asset risk. Z2= natural logarithm of Z2, a measure of leverage risk. FS: dummy variable that takes the value of one if the bank owns on foreign subsidiary or more, zero otherwise. ASdate, GFC, Islamic, and Window are dummy variables that take the value of one if the date is 2011 or 2012, 2008 or 2009, if the bank is considered Islamic, and if the bank is conventional with an Islamic window, respectively, or zero otherwise. FS_AS: interaction between ASdate and FS. FS_GFC: interaction between FS and GFC. GOBs: percentage of bank ownership held by governmental institutes. OC: percentage of the highest shareholder shares. CAR: the ratio of equity to total assets. NPL: ratio of impaired loans to total loans. Size: natural logarithm of assets. Divers $=1-\mid$ (net interest revenue - other operating income) / operating income $\mid \mathrm{HHI}=$ Herfindhal-Hirschman index, a measure of market concentration. GGL: growth of gross loans. GDP: natural logarithm of GDP per capita. GDP_Growth: annual growth rate of GDP per capita. FI_growth: annual growth rate of foreign investments. 
Table 12: MENA banks stability and the effects of the 'Arab Spring' (Hausman Taylor model) continuous foreign subsidiaries.

\begin{tabular}{|c|c|c|c|c|c|c|}
\hline & $\begin{array}{c}\text { Z-score } \\
1\end{array}$ & $\begin{array}{c}\mathrm{Z1} \\
2\end{array}$ & $\begin{array}{c}Z 2 \\
3\end{array}$ & $\begin{array}{c}\text { Z-score } \\
4\end{array}$ & $\begin{array}{c}\mathrm{Z1} \\
5\end{array}$ & $\begin{array}{c}Z 2 \\
6\end{array}$ \\
\hline ASdate & $\begin{array}{c}0.333^{* * *} \\
(0.0892)\end{array}$ & $\begin{array}{c}0.0861 \\
(0.1040)\end{array}$ & $\begin{array}{c}0.343 * * * \\
(0.0872)\end{array}$ & & & \\
\hline GFC & & & & $\begin{array}{c}-0.303^{* * *} \\
(0.0710)\end{array}$ & $\begin{array}{c}-0.222^{* * *} \\
(0.0835)\end{array}$ & $\begin{array}{c}-0.316^{* * *} \\
(0.0697)\end{array}$ \\
\hline FS_C & $\begin{array}{c}-0.0256^{* * *} \\
(0.0069)\end{array}$ & $\begin{array}{l}-0.0078 \\
(0.0137)\end{array}$ & $\begin{array}{c}-0.0220^{* * *} \\
(0.0067)\end{array}$ & $\begin{array}{c}-0.0234 * * * \\
(0.0088)\end{array}$ & $\begin{array}{c}-0.0085 \\
(0.0143)\end{array}$ & $\begin{array}{c}-0.0204 * * \\
(0.0086)\end{array}$ \\
\hline FS_AS_C & $\begin{array}{c}0.0321 * * \\
(0.0126)\end{array}$ & $\begin{array}{c}0.0128 \\
(0.0146)\end{array}$ & $\begin{array}{c}0.0323^{* * *} \\
(0.0122)\end{array}$ & & & \\
\hline FS_GFC_C & & & & $\begin{array}{l}-0.0008 \\
(0.0088)\end{array}$ & $\begin{array}{c}0.0090 \\
(0.0127)\end{array}$ & $\begin{array}{c}0.0004 \\
(0.0086)\end{array}$ \\
\hline GOBs & $\begin{array}{c}0.0023 \\
(0.0032)\end{array}$ & $\begin{array}{l}-0.0037 \\
(0.0037)\end{array}$ & $\begin{array}{c}0.0017 \\
(0.0029)\end{array}$ & $\begin{array}{c}0.0014 \\
(0.0032)\end{array}$ & $\begin{array}{l}-0.0040 \\
(0.0036)\end{array}$ & $\begin{array}{c}0.0008 \\
(0.0028)\end{array}$ \\
\hline Islamic & $\begin{array}{l}-0.2500 \\
(0.2180)\end{array}$ & $\begin{array}{c}-0.760 * * * \\
(0.2610)\end{array}$ & $\begin{array}{l}-0.2310 \\
(0.2000)\end{array}$ & $\begin{array}{l}-0.2240 \\
(0.2180)\end{array}$ & $\begin{array}{c}-0.746 * * * \\
(0.2510)\end{array}$ & $\begin{array}{l}-0.2000 \\
(0.1930)\end{array}$ \\
\hline Window & $\begin{array}{l}-0.0185 \\
(0.2320)\end{array}$ & $\begin{array}{l}-0.1250 \\
(0.2750)\end{array}$ & $\begin{array}{c}-0.0968 \\
(0.2110)\end{array}$ & $\begin{array}{l}-0.1180 \\
(0.2310)\end{array}$ & $\begin{array}{l}-0.1580 \\
(0.2650)\end{array}$ & $\begin{array}{l}-0.1990 \\
(0.2030)\end{array}$ \\
\hline OC & $\begin{array}{c}-0.00537^{*} \\
(0.0029)\end{array}$ & $\begin{array}{c}0.0002 \\
(0.0035)\end{array}$ & $\begin{array}{c}-0.00470 * \\
(0.0027)\end{array}$ & $\begin{array}{l}-0.0043 \\
(0.0029)\end{array}$ & $\begin{array}{c}0.0006 \\
(0.0034)\end{array}$ & $\begin{array}{l}-0.0036 \\
(0.0026)\end{array}$ \\
\hline CAR & $\begin{array}{c}0.1430 \\
(1.1620)\end{array}$ & $\begin{array}{c}2.1530 \\
(1.5350)\end{array}$ & $\begin{array}{c}1.3390 \\
(1.3220)\end{array}$ & $\begin{array}{c}0.4210 \\
(1.1600)\end{array}$ & $\begin{array}{c}2.3320 \\
(1.5210)\end{array}$ & $\begin{array}{c}1.7190 \\
(1.3170)\end{array}$ \\
\hline NPL & $\begin{array}{l}-0.0054 \\
(0.0045)\end{array}$ & $\begin{array}{l}-0.0112^{*} \\
(0.0060)\end{array}$ & $\begin{array}{c}-0.0042 \\
(0.0045)\end{array}$ & $\begin{array}{c}-0.0043 \\
(0.0045)\end{array}$ & $\begin{array}{l}-0.0109 * \\
(0.0060)\end{array}$ & $\begin{array}{l}-0.0026 \\
(0.0045)\end{array}$ \\
\hline SIZE & $\begin{array}{c}0.1280 \\
(0.0913)\end{array}$ & $\begin{array}{c}0.209 * \\
(0.1110)\end{array}$ & $\begin{array}{c}0.1150 \\
(0.0861)\end{array}$ & $\begin{array}{c}0.237 * * * \\
(0.0906)\end{array}$ & $\begin{array}{l}0.246 * * \\
(0.1090)\end{array}$ & $\begin{array}{c}0.222 * * * \\
(0.0844)\end{array}$ \\
\hline Divers & $\begin{array}{c}-0.442^{* *} \\
(0.1990)\end{array}$ & $\begin{array}{l}-0.3200 \\
(0.2360)\end{array}$ & $\begin{array}{l}-0.491 * * \\
(0.1950)\end{array}$ & $\begin{array}{c}-0.540 * * * \\
(0.2000)\end{array}$ & $\begin{array}{l}-0.3490 \\
(0.2330)\end{array}$ & $\begin{array}{c}-0.601 * * * \\
(0.1940)\end{array}$ \\
\hline $\mathrm{HHI}$ & $\begin{array}{c}1.1590 \\
(1.9490)\end{array}$ & $\begin{array}{c}1.5190 \\
(2.2360)\end{array}$ & $\begin{array}{c}1.3510 \\
(1.9040)\end{array}$ & $\begin{array}{c}2.1890 \\
(1.9810)\end{array}$ & $\begin{array}{c}2.1540 \\
(2.2430)\end{array}$ & $\begin{array}{c}2.5380 \\
(1.9430)\end{array}$ \\
\hline GGL & $\begin{array}{c}-0.00409 * * * \\
(0.0014)\end{array}$ & $\begin{array}{c}-0.00348 * * \\
(0.0016)\end{array}$ & $\begin{array}{c}-0.00419^{* * *} \\
(0.0014)\end{array}$ & $\begin{array}{c}-0.00488^{* * *} \\
(0.0014)\end{array}$ & $\begin{array}{c}-0.00370^{* *} \\
(0.0016)\end{array}$ & $\begin{array}{c}-0.00489 * * * \\
(0.0014)\end{array}$ \\
\hline GDP & $\begin{array}{c}0.0429 \\
(0.1930)\end{array}$ & $\begin{array}{l}-0.0137 \\
(0.2210)\end{array}$ & $\begin{array}{c}0.0376 \\
(0.1890)\end{array}$ & $\begin{array}{c}0.483^{* * *} \\
(0.1730)\end{array}$ & $\begin{array}{c}0.1650 \\
(0.1980)\end{array}$ & $\begin{array}{c}0.500 * * * \\
(0.1690)\end{array}$ \\
\hline GDP_Growth & $\begin{array}{c}0.0453^{* * *} \\
(0.0105)\end{array}$ & $\begin{array}{c}0.0525^{* * *} \\
(0.0121)\end{array}$ & $\begin{array}{c}0.0479 * * * \\
(0.0103)\end{array}$ & $\begin{array}{c}0.0344^{* * *} \\
(0.0104)\end{array}$ & $\begin{array}{c}0.0485^{* * *} \\
(0.0119)\end{array}$ & $\begin{array}{c}0.0366 * * * \\
(0.0102)\end{array}$ \\
\hline FI_Growth & $\begin{array}{l}-0.0215 \\
(0.0184)\end{array}$ & $\begin{array}{l}-0.0106 \\
(0.0217)\end{array}$ & $\begin{array}{l}-0.0208 \\
(0.0179)\end{array}$ & $\begin{array}{l}-0.0114 \\
(0.0185)\end{array}$ & $\begin{array}{l}-0.0072 \\
(0.0215)\end{array}$ & $\begin{array}{l}-0.0101 \\
(0.0181)\end{array}$ \\
\hline _cons & $\begin{array}{c}1.4610 \\
(1.8020)\end{array}$ & $\begin{array}{l}-1.0030 \\
(2.1050)\end{array}$ & $\begin{array}{c}1.3360 \\
(1.7360)\end{array}$ & $\begin{array}{l}-3.955^{* *} \\
(1.5930)\end{array}$ & $\begin{array}{l}-3.130 * \\
(1.8630)\end{array}$ & $\begin{array}{c}-4.267^{* * *} \\
(1.5310)\end{array}$ \\
\hline $\begin{array}{l}\mathrm{N} \\
\text { country effect } \\
\text { control }\end{array}$ & $\begin{array}{l}929 \\
\text { Yes }\end{array}$ & $\begin{array}{l}879 \\
\text { Yes }\end{array}$ & $\begin{array}{l}916 \\
\text { Yes }\end{array}$ & $\begin{array}{l}929 \\
\text { Yes }\end{array}$ & $\begin{array}{l}879 \\
\text { Yes }\end{array}$ & $\begin{array}{l}916 \\
\text { Yes }\end{array}$ \\
\hline
\end{tabular}

Standard errors are between parentheses. $*, * *$, and $* * *$ indicate statistical significance at $10 \%, 5 \%$, and $1 \%$, respectively. 
Z-score= Natural logarithm of Z-score, a measure of stability. Z1= natural logarithm of Z1, a measure of bank asset risk. Z2 = natural logarithm of Z2, a measure of leverage risk. FS_C: continuous variable representing the actual number of foreign subsidiaries owned by each bank. ASdate, GFC, Islamic, and Window are dummy variables that take the value of one if the date is 2011 or 2012, 2008 or 2009, if the bank is considered Islamic, and if the bank is conventional with an Islamic window, respectively, or zero otherwise. FS_AS_C: interaction between ASdate and FS_C. FS_GFC_C: interaction between FS_C and GFC. GOBs: percentage of bank ownership held by governmental institutes. OC: percentage of the highest shareholder shares. CAR: the ratio of equity to total assets. NPL: ratio of impaired loans to total loans. Size: natural logarithm of assets. Divers $=1-$ | (net interest revenue - other operating income) / operating income $\mid$. $\mathrm{HHI}=$ Herfindhal-Hirschman index, a measure of market concentration. GGL: growth of gross loans. GDP: natural logarithm of GDP per capita. GDP_Growth: annual growth rate of GDP per capita. FI_growth: annual growth rate of foreign investments. 
Table 13: MENA banks stability and the effects of the 'Arab Spring' (Hausman Taylor model) excluding non-Arab countries.

\begin{tabular}{|c|c|c|c|c|c|c|}
\hline & $\begin{array}{l}\text { Z-score } \\
1\end{array}$ & $\begin{array}{l}Z 1 \\
2\end{array}$ & $\begin{array}{l}Z 2 \\
3\end{array}$ & $\begin{array}{l}\text { Z-score } \\
4\end{array}$ & $\begin{array}{l}Z 1 \\
5\end{array}$ & $\begin{array}{l}Z 2 \\
6\end{array}$ \\
\hline ASdate & $\begin{array}{l}0.283^{* *} \\
(0.0180)\end{array}$ & $\begin{array}{l}0.0103 \\
(0.9380)\end{array}$ & $\begin{array}{l}0.327 * * * \\
(0.0050)\end{array}$ & & & \\
\hline GFC & & & & $\begin{array}{l}-0.308 * * * \\
(0.0050)\end{array}$ & $\begin{array}{l}-0.277^{* *} \\
(0.0210)\end{array}$ & $\begin{array}{l}-0.307 * * * \\
(0.0040)\end{array}$ \\
\hline FS & $\begin{array}{l}-0.428 * * \\
(0.0220)\end{array}$ & $\begin{array}{l}-0.1630 \\
(0.4700)\end{array}$ & $\begin{array}{l}-0.346^{* *} \\
(0.0500)\end{array}$ & $\begin{array}{l}-0.456 * * \\
(0.0130)\end{array}$ & $\begin{array}{l}-0.1830 \\
(0.4040)\end{array}$ & $\begin{array}{l}-0.376 * * \\
(0.0260)\end{array}$ \\
\hline FS_AS & $\begin{array}{l}0.280 * * \\
(0.0410)\end{array}$ & $\begin{array}{l}0.2280 \\
(0.1360)\end{array}$ & $\begin{array}{l}0.223^{*} \\
(0.0960)\end{array}$ & & & \\
\hline FS_GFC & & & & $\begin{array}{l}-0.0353 \\
(0.7980)\end{array}$ & $\begin{array}{l}0.1090 \\
(0.4730)\end{array}$ & $\begin{array}{l}-0.0412 \\
(0.7610)\end{array}$ \\
\hline GOBs & $\begin{array}{l}0.0008 \\
(0.7890)\end{array}$ & $\begin{array}{l}-0.0052 \\
(0.1800)\end{array}$ & $\begin{array}{l}0.0003 \\
(0.9130)\end{array}$ & $\begin{array}{l}0.0004 \\
(0.9030)\end{array}$ & $\begin{array}{l}-0.0055 \\
(0.1390)\end{array}$ & $\begin{array}{l}-0.0003 \\
(0.9180)\end{array}$ \\
\hline Islamic & $\begin{array}{l}-0.2750 \\
(0.2150)\end{array}$ & $\begin{array}{l}-0.793 * * * \\
(0.0040)\end{array}$ & $\begin{array}{l}-0.2560 \\
(0.2170)\end{array}$ & $\begin{array}{l}-0.2220 \\
(0.2940)\end{array}$ & $\begin{array}{l}-0.774 * * * \\
(0.0030)\end{array}$ & $\begin{array}{l}-0.2040 \\
(0.2900)\end{array}$ \\
\hline Window & $\begin{array}{l}-0.0125 \\
(0.9570)\end{array}$ & $\begin{array}{l}-0.0590 \\
(0.8410)\end{array}$ & $\begin{array}{l}-0.0821 \\
(0.7060)\end{array}$ & $\begin{array}{l}-0.1250 \\
(0.5780)\end{array}$ & $\begin{array}{l}-0.1210 \\
(0.6680)\end{array}$ & $\begin{array}{l}-0.1980 \\
(0.3310)\end{array}$ \\
\hline OC & $\begin{array}{l}-0.00717^{* *} \\
(0.0210)\end{array}$ & $\begin{array}{l}-0.0023 \\
(0.5620)\end{array}$ & $\begin{array}{l}-0.00665^{* *} \\
(0.0220)\end{array}$ & $\begin{array}{l}-0.00657^{* *} \\
(0.0270)\end{array}$ & $\begin{array}{l}-0.0019 \\
(0.6080)\end{array}$ & $\begin{array}{l}-0.00609 * * \\
(0.0260)\end{array}$ \\
\hline CAR & $\begin{array}{l}0.6150 \\
(0.5960)\end{array}$ & $\begin{array}{l}2.587^{*} \\
(0.0790)\end{array}$ & $\begin{array}{l}1.9010 \\
(0.1450)\end{array}$ & $\begin{array}{l}0.5710 \\
(0.6250)\end{array}$ & $\begin{array}{l}2.507^{*} \\
(0.0880)\end{array}$ & $\begin{array}{l}1.9430 \\
(0.1360)\end{array}$ \\
\hline NPL & $\begin{array}{l}-0.0031 \\
(0.4970)\end{array}$ & $\begin{array}{l}-0.0078 \\
(0.1790)\end{array}$ & $\begin{array}{l}-0.0019 \\
(0.6650)\end{array}$ & $\begin{array}{l}-0.0019 \\
(0.6840)\end{array}$ & $\begin{array}{l}-0.0079 \\
(0.1720)\end{array}$ & $\begin{array}{l}0.0001 \\
(0.9850)\end{array}$ \\
\hline SIZE & $\begin{array}{l}0.1200 \\
(0.2230)\end{array}$ & $\begin{array}{l}0.1720 \\
(0.1180)\end{array}$ & $\begin{array}{l}0.1230 \\
(0.1940)\end{array}$ & $\begin{array}{l}0.232 * * \\
(0.0230)\end{array}$ & $\begin{array}{l}0.238 * * \\
(0.0350)\end{array}$ & $\begin{array}{l}0.233^{* *} \\
(0.0170)\end{array}$ \\
\hline Divers & $\begin{array}{l}-0.2730 \\
(0.1840)\end{array}$ & $\begin{array}{l}-0.1800 \\
(0.4530)\end{array}$ & $\begin{array}{l}-0.3180 \\
(0.1160)\end{array}$ & $\begin{array}{l}-0.442 * * \\
(0.0310)\end{array}$ & $\begin{array}{l}-0.2580 \\
(0.2730)\end{array}$ & $\begin{array}{l}-0.493 * * \\
(0.0140)\end{array}$ \\
\hline $\mathrm{HHI}$ & $\begin{array}{l}-0.4090 \\
(0.8700)\end{array}$ & $\begin{array}{l}-4.617^{*} \\
(0.0950)\end{array}$ & $\begin{array}{l}-0.2710 \\
(0.9110)\end{array}$ & $\begin{array}{l}0.3340 \\
(0.8950)\end{array}$ & $\begin{array}{l}-4.3010 \\
(0.1200)\end{array}$ & $\begin{array}{l}0.6090 \\
(0.8060)\end{array}$ \\
\hline GGL & $\begin{array}{l}-0.00374 * * * \\
(0.0070)\end{array}$ & $\begin{array}{l}-0.00359 * * \\
(0.0260)\end{array}$ & $\begin{array}{l}-0.00376 * * * \\
(0.0070)\end{array}$ & $\begin{array}{l}-0.00450 * * * \\
(0.0010)\end{array}$ & $\begin{array}{l}-0.00378 * * \\
(0.0180)\end{array}$ & $\begin{array}{l}-0.00444 * * * \\
(0.0020)\end{array}$ \\
\hline GDP & $\begin{array}{l}-0.1550 \\
(0.4380)\end{array}$ & $\begin{array}{l}-0.3040 \\
(0.1670)\end{array}$ & $\begin{array}{l}-0.1560 \\
(0.4280)\end{array}$ & $\begin{array}{l}0.315^{*} \\
(0.0870)\end{array}$ & $\begin{array}{l}-0.1520 \\
(0.4540)\end{array}$ & $\begin{array}{l}0.334 * \\
(0.0640)\end{array}$ \\
\hline GDP_Growth & $\begin{array}{l}0.0452^{* * *} \\
0.0000\end{array}$ & $\begin{array}{l}0.0566^{* * *} \\
0.0000\end{array}$ & $\begin{array}{l}0.0482^{* * *} \\
0.0000\end{array}$ & $\begin{array}{l}0.0362 * * * \\
(0.0010)\end{array}$ & $\begin{array}{l}0.0549 * * * \\
0.0000\end{array}$ & $\begin{array}{l}0.0387^{* * *} \\
0.0000\end{array}$ \\
\hline FI_Growth & $\begin{array}{l}-0.0130 \\
(0.4770)\end{array}$ & $\begin{array}{l}-0.0155 \\
(0.4550)\end{array}$ & $\begin{array}{l}-0.0130 \\
(0.4670)\end{array}$ & $\begin{array}{l}-0.0037 \\
(0.8420)\end{array}$ & $\begin{array}{l}-0.0126 \\
(0.5420)\end{array}$ & $\begin{array}{l}-0.0036 \\
(0.8400)\end{array}$ \\
\hline _cons & $\begin{array}{l}3.1640 \\
(0.1660)\end{array}$ & $\begin{array}{l}2.7620 \\
(0.2740)\end{array}$ & $\begin{array}{l}2.8640 \\
(0.1970)\end{array}$ & $\begin{array}{l}-2.1560 \\
(0.3100)\end{array}$ & $\begin{array}{l}0.5490 \\
(0.8140)\end{array}$ & $\begin{array}{l}-2.6580 \\
(0.1970)\end{array}$ \\
\hline $\begin{array}{l}\mathrm{N} \\
\text { Country Effect } \\
\text { control }\end{array}$ & $\begin{array}{l}854 \\
\text { Yes }\end{array}$ & $\begin{array}{l}807 \\
\text { Yes }\end{array}$ & $\begin{array}{l}842 \\
\text { Yes }\end{array}$ & $\begin{array}{l}854 \\
\text { Yes }\end{array}$ & $\begin{array}{l}807 \\
\text { Yes }\end{array}$ & $\begin{array}{l}842 \\
\text { Yes }\end{array}$ \\
\hline
\end{tabular}

Standard errors are between parentheses. $*, * *$, and $* * *$ indicate statistical significance at $10 \%, 5 \%$, and $1 \%$, respectively. 
Z-score= Natural logarithm of Z-score, a measure of stability. Z1= natural logarithm of Z1, a measure of bank asset risk. Z2 = natural logarithm of Z2, a measure of leverage risk (Z-score, Z1 and Z2 are calculated using a two year moving window). FS: dummy variable that takes the value of one if the bank owns on foreign subsidiary or more, zero otherwise. ASdate, GFC, Islamic, and Window are dummy variables that take the value of one if the date is 2011 or 2012, 2008 or 2009, if the bank is considered Islamic, and if the bank is conventional with an Islamic window, respectively, or zero otherwise. FS_AS: interaction between ASdate and FS. FS_GFC: interaction between FS and GFC. GOBs: percentage of bank ownership held by governmental institutes. OC: percentage of the highest shareholder shares. CAR: the ratio of equity to total assets. NPL: ratio of impaired loans to total loans. Size: natural logarithm of assets. Divers $=1-$ | (net interest revenue - other operating income) / operating incomel. $\mathrm{HHI}=$ Herfindhal-Hirschman index, a measure of market concentration. GGL: growth of gross loans. GDP: natural logarithm of GDP per capita. GDP_Growth: annual growth rate of GDP per capita. FI_growth: annual growth rate of foreign investments. 